\title{
Mormons and Early Iowa History (1838 to 1858$)$ : Eight Distinct Connections
}

\author{
WILLIAM G. HARTLEY
}

MORMON CONNECTIONS to Iowa are noted in early Iowa histories, linger in local and family lore, and show up on Iowa's landscapes and maps. ${ }^{1}$ Evidence of and stories about Mormon wagon ruts, swales, graves, wells, camping sites, cabins, enterprises, and place names are found in the broad swath of southern Iowa counties through which the Mormon Trail and its alternates passed, and along the I- 80 corridor from Iowa City to Council Bluffs. Unfortunately, observers often confuse or conflate the various connections between Mormons and early Iowa history.

It is common, for instance, to link all such connections to the two best-known Mormon connections to Iowa: the 1846 wagon companies led by Brigham Young and the 1856-57 handcart brigades. While some Mormon imprints in Iowa do stem from those two groups, others do not. ${ }^{2}$ In fact, the Mormons had at

1. A convenient bibliography of a dozen early Iowa county histories is in endnotes in Thomas J. Morain, "Mormons and Nineteenth-Century Iowa Historians," John Whitmer Historical Association Journal 1 (1981), 34-42.

2. Two recent publications show why this primer is needed. A 1994 travel booklet, Pella Iowa: A Touch of Holland, says 12,000 Mormon wagons (should be people) crossed Iowa in 1845 (should be 1846), and that a Mormon group passed through Pella that year (not true). In fact, LDS companies passed through Pella much later, in 1853 (see connection 6 below). Also, only partial understanding of the 1846 exodus and subsequent Mormon contacts are conveyed in Ruth S. Beitz, "Where the Saints Have Trod," Iowan 44 (Fall 1995), 40-47.

THE ANNALS OF IOWA 59 (Summer 2000). (C) The State Historical Society of Iowa, 2000. 
least eight distinct connections with early Iowa history (1838 to 1858): (1) Mormon fugitives from Missouri and the Mormon Trace in Appanoose and Davis Counties (1838); (2) Nauvooperiod Mormon settlements in and near Lee County (1839-1846); (3) the Emmett Company Expedition (1844-1846); (4) the threestage Mormon Exodus from Nauvoo (1846); (5) Kanesville (early Council Bluffs), Mormon hub and outfitting city (18461852); (6) Keokuk as Mormon wagon train outfitting camp (1853); (7) LDS handcart and wagon companies (1856-1858); and (8) Mormons who did not go west.

This article is designed to explain and explore these eight separate connections, to offer perspective and needed interpretations, to identify inaccurate information in circulation, and to provide generous bibliographic references to the best studies available. Summaries of each connection are based on the best and most recent factual information available. The concise histories and reference material are intended to help scholars and lay people, non-Mormons and Mormons, deal with Mormon matters they encounter in early Iowa records, in current lore, or on site, thereby helping both Mormon and Iowa history be more accurate and reliable. ${ }^{3}$

OFFICIALLY, "Mormons" belong to The Church of Jesus Christ of Latter-day Saints. Because that name is long, the church is often referred to simply as the LDS Church or Mormon Church, and its members are called Latter-day Saints, Saints, or Mormons. The nickname Mormon stems from the Book of Mormon, a volume that church members accept as scripture.

3. Over the years the Annals of Iowa has published several articles about some Mormon connections. Also, the 1846 Mormon Trail received considerable attention during 1996, one result being Susan Easton Black and William G. Hartley, eds., The Iowa Mormon Trail: Legacy of Faith and Courage (Orem, UT, 1997). Since 1995, the Iowa Mormon Trails Association and its local chapters have published guides and booklets about the Iowa Mormon Trail. Chapters 1-4 of Stanley B. Kimball, Historic Sites and Markers along the Mormon and Other Great Western Trails (Urbana and Chicago, 1988) are devoted to Iowa. The standard history about the Mormon handcart brigades is LeRoy R. Hafen and Ann W. Hafen, Handcarts to Zion: The Story of a Unique Western Migration, 1856-1860, with Contemporary Journals, Accounts, Reports, and Rosters of Members of the Ten Handcart Companies (1960; reprint, Spokane, WA, and Lincoln, NE, 1992). 


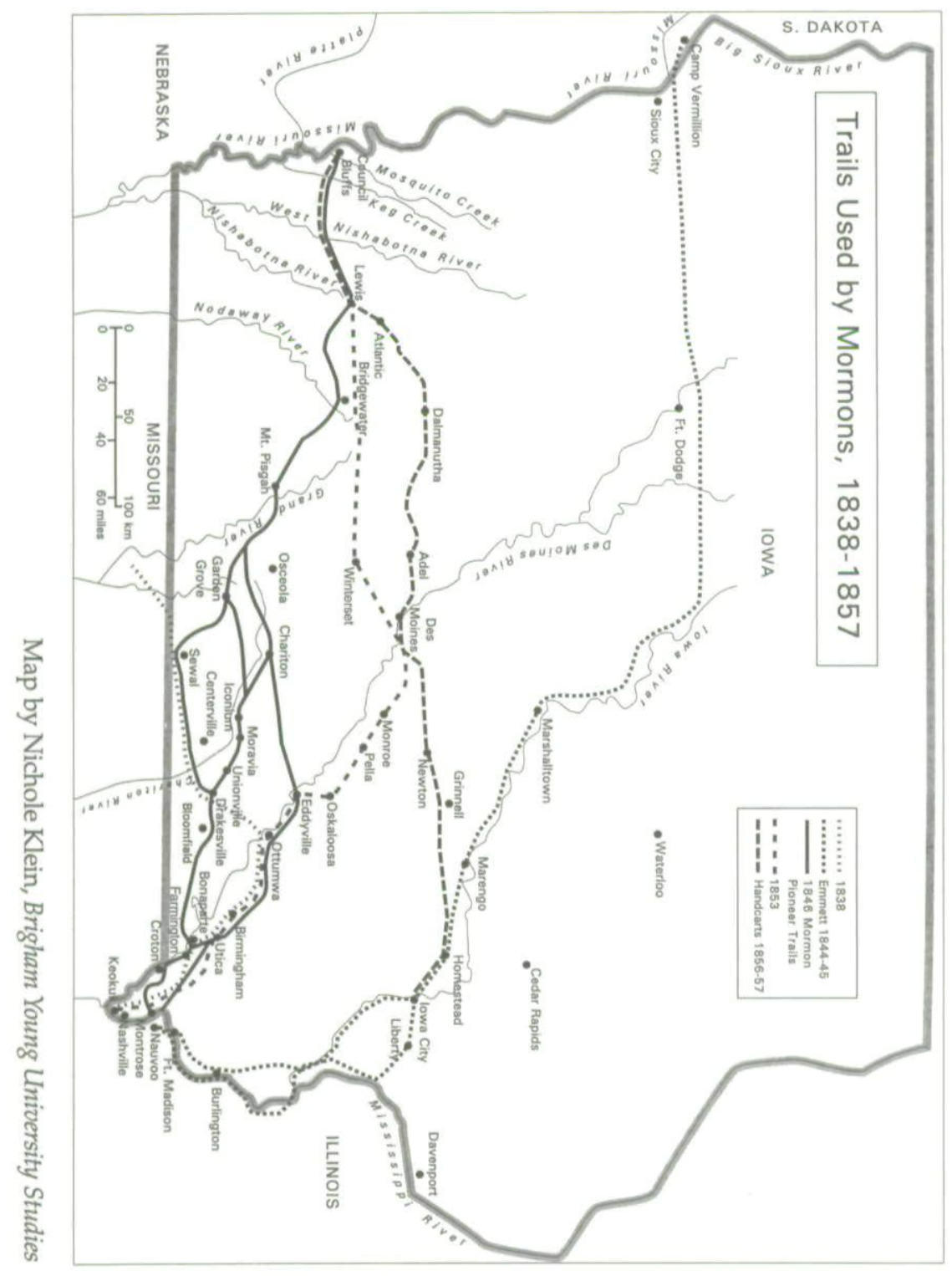


Several responsible studies explain LDS beliefs and history for the 1838-1858 period. ${ }^{4}$ Founded by Joseph Smith in upstate New York in 1830, Mormonism proclaimed itself to be the restored version of the church Christ established. Mormons consider Smith a modern prophet who received revelations, including the Book of Mormon. During the 1830s, baptized converts responded to a doctrinal call to "gather" in and around Kirtland, Ohio, and Independence, Missouri. In 1838, conflicts with Missourians forced the Mormons, then numbering about 10,000, to seek refuge in Illinois. In 1839 they established several settlements along the Mississippi River. Nauvoo, Illinois, 15 miles upriver from Keokuk, Iowa, became their chief city and the headquarters for their church. While builders constructed an impressive white temple to be Nauvoo's centerpiece, the city's population swelled to 12,000 at its peak. Ultimately, some 4,000 to 6,000 more lived nearby, including hundreds across the river in Iowa Territory. The region's LDS population never exceeded 20,000 , and probably peaked at about 17,000 . $^{5}$

In 1844 anti-Mormon mobs killed Joseph Smith and his brother Hyrum in the Carthage, Illinois, jail. A year later the beleaguered believers, led by Brigham Young, the senior member of the church's Quorum of Twelve Apostles, agreed to leave Illinois and head west to find a safe gathering place in the Rocky Mountains. Through the winter of $1845-46$ the people built wagons, stockpiled materials, sold properties, and prepared to leave in the spring of 1846.

4. Useful and responsible one-volume histories of the LDS Church are James B. Allen and Glen M. Leonard, The Story of the Latter-day Saints, rev. ed. (Salt Lake City, 1992); and Leonard J. Arrington and Davis Bitton, The Mormon Experience: A History of the Latter-day Saints (New York, 1979). For analytical religious studies, see Klaus J. Hansen, Mormomism and the American Experience (Chicago, 1981); and Jan Shipps, Mormonism: The Story of a New Religious Tradition (Urbana and Chicago, 1985). For Nauvoo history, see Robert B. Flanders, Nauvoo: Kingdom on the Mississippi (Urbana, 1965); Roger D. Launius and John E. Hallwas, eds., Kingdom on the Mississippi Revisited: Nauvoo in Mormon History (Urbana and Chicago, 1996); and David E. Miller and Della S. Miller, Nauvoo: The City of Joseph (Santa Barbara and Salt Lake City, 1974). A superior biography of Brigham Young is Leonard J. Arrington, Brigham Young: American Moses (New York, 1985).

5. Some sources exaggerate the region's Mormon population. My population estimates rely on Susan Easton Black's careful calculations in "How Large Was the Population of Nauvoo?" Brigham Young University Studies 35 (1995), 91-95. 
During an eight-month interval in 1846, they vacated the Nauvoo area, and by 1852 at least three-fourths of them had relocated to Utah, while a small minority declined to go west. Great Salt Lake City became the church's new headquarters. Meanwhile, converts from elsewhere in the United States and Europe constantly flowed to Iowa and Nebraska to begin their treks west. Agents of the church's Perpetual Emigrating Fund moved emigrants annually by ship, boat, train, and wagon train to Utah, or "Zion." Between 1846 and 1868 approximately 70,000 believers gathered in Utah. Based on a revelation to Smith, some Mormons began practicing plural marriage (polygamy) in Nauvoo and Utah. The practice was kept secret until it was publicly announced as a church tenet in 1852 . Nonetheless, the practice affected how Iowans reacted to Mormons on their soil, and it caused some Mormons to choose not to go west. The church gave up the practice by the turn of the century. Today, the LDS church has $11,000,000$ members worldwide, with about 18,000 in Iowa. ${ }^{6}$

Some Mormons formed separate churches espousing their own versions of the religion. The most prominent has been the Reorganized Church of Jesus Christ of Latter Day Saints, or RLDS church, which organized in 1860 in Illinois and won many adherents in Iowa. Renamed the Community of Christ effective in 2001, its worldwide membership is approximately 250,000 .

\section{Connection 1: Mormon Fugitives from Missouri and the Mor-} mon Trace in Appanoose and Davis Counties (1838). The federal government surveyed Davis County in 1843 and Appanoose County in 1843 and 1844. The original Government Land Office maps-prime sources for early Iowa history-show a distinct "Mormon Trail" across Davis County, which continues as a "Mormon Trace" across Appanoose County. This Mormon imprint on Iowa predates the Nauvoo exodus by eight years.

In late 1838 Iowa became an escape route for dozens of Mormon militiamen fleeing northward to avoid arrest for par-

6. Most standard histories of Mormonism (see fn. 4) discuss the LDS church's practice of plural marriage and its phase-out between 1890 and 1904 . For current membership statistics, see 1999-2000 Church Almanac (Salt Lake City, 1998), p. 6 (church total) and p. 203 (Iowa total). 
ticipating in the Mormon War in Missouri, particularly the "Battle of Crooked River." ${ }^{\prime 7}$ Leaving Caldwell and Daviess Counties, these men moved northeasterly until they entered an unsettled area of Iowa Territory in present Appanoose County's southwest corner. They headed east, then veered north to the Fox River near where Drakesville is now. There they again headed east and eventually reached the Mississippi River.

There is no published account of the dozens of Mormons who took that route, but a few participants did record their experiences. On November 1 and 2, 1838, a group of two dozen fugitives including Charles C. Rich fled from Far West, Missouri, hurrying "for Iowa through the wilderness." They suffered from cold and snow and "had but little to eat." After eleven days they "reached the white Settlements on the Desmoine River" and headed for the Mississippi River. $^{8}$ The same night that Rich's group left, Dimick Huntington and others also left Far West. This horseback company took a northeastly course "through timber and prairie" and forded several streams. In Iowa they rode near where Drakesville now is and moved north at least as far as present Ottumwa. They passed Chief Black Hawk's burial site (between present-day Eldon and Selma), Utica, and West Point, and crossed the Mississippi River near Fort Madison. ${ }^{9}$

\footnotetext{
7. Alexander L. Baugh, "A Call to Arms: The 1838 Mormon Defense of Northern Missouri" (Ph.D. diss., Brigham Young University, 1996), is the best-researched presentation to date and is sympathetic to the Mormon side of the conflict. Stephen C. LeSueur, The 1838 Mormon War in Missouri (Columbia, MO, 1987), favors the Missourians' justifications for the removal of the Mormons.
}

8. Charles C. Rich, "A Sketch That I Was An Eye Witness to in the State of Missouri," holograph, Charles C. Rich Papers, LDS Church Historical Department Archives, Salt Lake City, Utah. Rich, born in Kentucky, became an LDS Church apostle in 1849 and was an important colonizer and community leader in northern Utah.

9. Dimick B. Huntington Journal, copied in LDS Journal History, 1 November 1838. The Journal History is a massive day-by-day history of the LDS church that incorporates contemporary clippings, diary quotations, and official records. It is located in the LDS Church Archives. It has an invaluable comprehensive index. Huntington was the son of William D. Huntington, who served during the 1846 LDS exodus from Nauvoo as president of the Mt. Pisgah settlement in Iowa, where he died. In 1846 Dimick, his wife, Fanny, and three children left Iowa in the Mormon Battalion, Co. D. 
In Huntington's group were Hosea Stout, later a Nauvoo policeman and a noted LDS diarist; Samuel Smith, brother of Mormon prophet Joseph Smith; and Phineas and Lorenzo Dow Young, brothers of Brigham Young. Local Iowa lore holds that Joseph Smith and Brigham Young were on that route in 183738-a story that confuses them with these Smith and Young siblings. ${ }^{10}$ Phineas Young, "a good woodsman," was the group's pilot, and Lorenzo Dow Young the cook. For safety they traveled the most secluded routes they could find. Game was scarce. Lacking food, by the time they entered Iowa they were so weak they could not go on. Religious men, they prayed for help. Samuel Smith said he was shown in his mind where they could find sustenance. He and two others went a short distance and found "an Indian wigwam," where an Indian woman, seeing their hunger, baked them cakes and sent more with them for the others. At the Mississippi near Fort Madison, part of the group crossed, while others waited several days until ice moved downriver. ${ }^{11}$

In 1845, Phineas Young again followed the 1838 Mormon Trace, but in reverse. He left Nauvoo, Illinois, on April 23 with four others and started west to do missionary work among American Indians beyond the Missouri River. At Farmington, Iowa, they crossed the Des Moines River, then followed the "Dragoon Trail" for five miles. Three days and 37 miles later, they "struck the old Mormon trail," turned left, and followed it for one mile. The next day they "followed the old trail thirty miles, found the country thrifty inhabited with only here and there a cabin in the timber, the inhabitants living to appearance mostly by hunting." Once across the Chariton River they

10. This Joseph Smith and Brigham Young myth comes from lore collected by J. C. Harvey of Seymour, Iowa, and published in the Iowegian in January 1934. It is perpetuated in the Appanoose County Mormon Trails Association's book, Mormon Trails Across Appanoose County, Iowa, ed. Willis M. Heusinkveld (Centerville, 1995), 11.

11. Preston Nibley, ed., History of Joseph Smith by His Mother, Lucy Mack Smith (Salt Lake City, UT, 1945), 298-99; Leonard J. Arrington, Charles C. Rich: Mormon General and Western Frontiersman (Provo, UT, 1974), 60-61; Juanita Brooks, ed., On the Mormon Frontier: The Diary of Hosea Stout, 1844-1861, 2 vols. (Salt Lake City, 1964), 1:xvi; Lorenzo Dow Young, "Recollections," in Four Faith Promoting Classics (Salt Lake City, 1978), 52-54. 
camped on Shoal Creek, where Phineas Young wrote in his diary, "This place is the same on which I had spent a cold night in company with twenty men in Nov. 1838 without food, and almost without raiment." They stayed on the 1838 Mormon Trace until they were well into Missouri. ${ }^{12}$

One year later, in 1846, Brigham Young's company found and followed this Mormon Trace. After crossing the Fox River within two miles south of present-day Drakesville, they encountered the trail and followed it for about 30 miles. Among those 2,000 Mormons were at least two who had blazed that route in 1838- Hosea Stout and Lorenzo Dow Young. Diarist Stout noted this reaction on March 20: "Struck the old Mormon trail. This was the trail which we made when I was in company with 27 others fled from Far West, Mo. . . It was with peculiar feeling that I saw this old trail. . . . a public road now occupied the same ground but was not much traveled." A week later Stout "had a talk with Br. Lorenzo Young about our travels on this road when we fled from Missouri." Four days later on the east side of the Chariton River, Stout recorded that he "found the place where I had encamped when fleeing from Missouri. It was but a short distance from the road." ${ }^{\prime 13}$

The "Mormon Trace" and "Mormon Trail" included on pre1846 Government Land Office maps for Appanoose and Davis Counties record the route Mormon parties took through those counties in 1838. That trail served many subsequent travelers, Mormons and non-Mormons, for at least a decade.

Connection 2: Nauvoo-period Mormon Settlements in and near Lee County (1839-1846). To end conflicts with Mormons in his state, Missouri's Governor Lilburn W. Boggs issued an "Extermination Order" on October 27, 1838, which decreed that Mormons "must be exterminated or driven from the state. ${ }^{14}$ In response, Mormons flooded east to Illinois and by mid-1839 were settling in and building up the area in and around Commerce,

12. Phineas Young's diary is quoted at length in Kenneth W. Godfrey, Charles Shumway: A Pioneer's Life (Provo, UT, 1974), 20-22.

13. Diary of Hosea Stout, 1:140, 145, 146.

14. LeSueur, The 1838 Mormon War in Missouri, 150-53. 


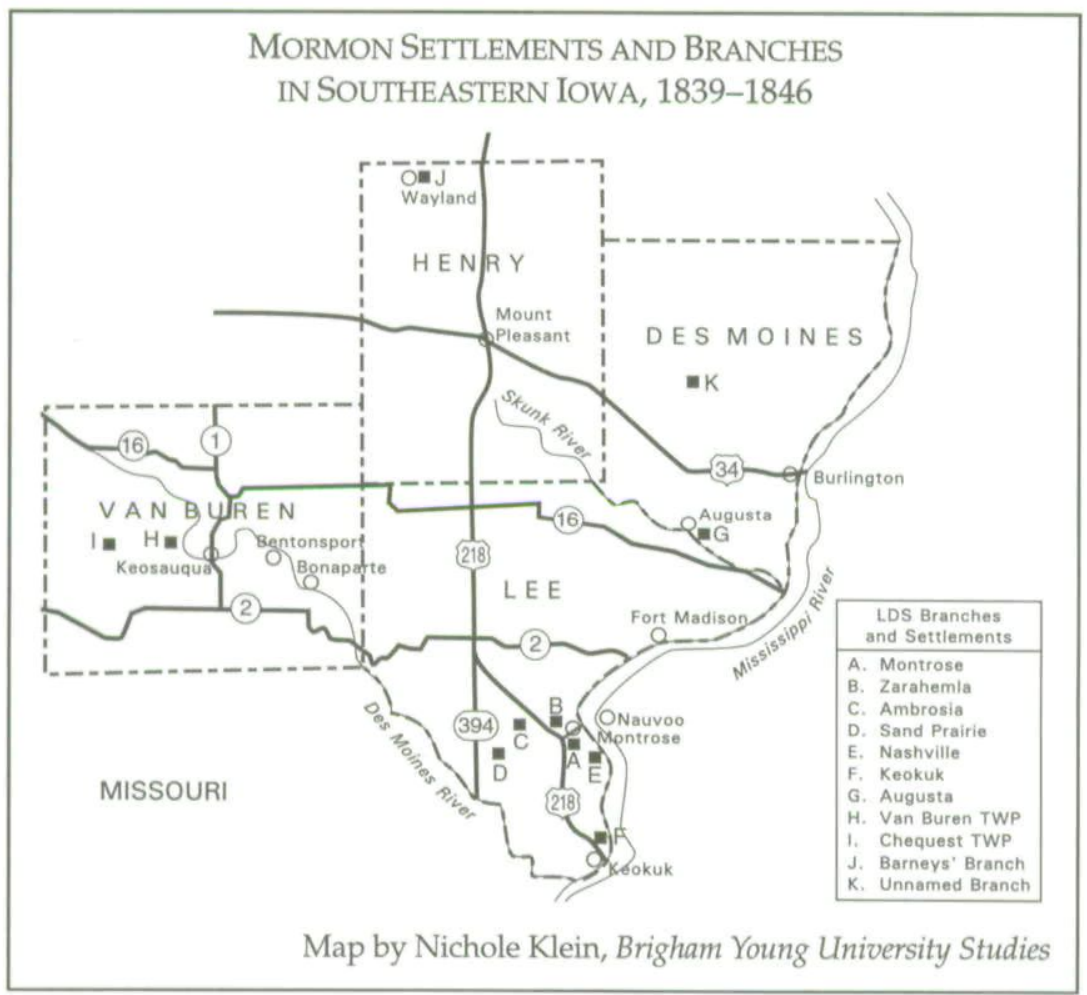

Illinois (renamed Nauvoo in 1840). Hundreds settled on the Iowa side of the Mississippi River. "In many ways," historian Stanley Kimball has noted, "the eastern part of Lee County may be considered as part of Greater Nauvoo." ${ }^{15}$ In June 1839 the church bought two extensive tracts of land in the triangular Half-breed Tract, which extended from Fort Madison west to the Des Moines River and south to Keokuk. The purchase included a town site three miles south of Montrose called Nashville (now Galland) and 20,000 acres around it and along the Mississippi River. The church bought another 30,000 acres in and around Montrose, including part of the Montrose town site.

15. Stanley B. Kimball, "Nauvoo West: The Mormons of the Iowa Shore," Brigham Young University Studies 18 (1978), 132; idem, "Eastern Iowa," in S. Kent Brown, et al, Historical Atlas of Mormonism (New York, 1994), 58-59; Donald Q. Cannon, "Mormon Satellite Settlements in Hancock County, Illinois, and Lee County, Iowa," in Black and Hartley, eds., The Iowa Mormon Trail, 21-34. 
Individual Saints, too, bought land in nearby Keokuk and settled in neighboring Des Moines and Van Buren Counties. ${ }^{16}$

In early 1839 some 40 LDS families occupied the deserted U.S. Army barracks of Old Fort Des Moines, located just across the river from where Nauvoo soon sprang up. Families residing there included those of church apostles Brigham Young, John Taylor, and Wilford Woodruff. The unattractive, spartan, Ushaped army barracks, which faced the Mississippi River, had been built in 1834 and abandoned in $1837 .^{17}$

Those Mormon-occupied barracks became the scene of a "day of healing," on July 22, 1839. That summer Mormons on both sides of the river suffered deadly sicknesses. Mormon prophet Joseph Smith, although ill himself, rose from his bed and ministered to the sick in Nauvoo, then crossed the river with five apostles, where he blessed and healed several, including Brigham Young. ${ }^{18}$

In 1839 Montrose was surveyed, streets were laid out, and a temple site selected. ${ }^{19}$ By that fall so many Saints lived in and around Montrose that the church established a stake organization there. ${ }^{20}$ This Iowa Stake, renamed Zarahemla Stake in 1841, had a stake presidency, high council, bishop, and nine branches or congregations that by 1841 included some 750 Mormons. In 1842 the Zarahemla Stake was disbanded and its people were

16. Kimball, "Nauvoo West," 136. I know of no property title searches yet done in Lee County land records to verify the actual amount of land the church owned. Individual Mormons did buy land, and their land titles should be factored into any assessment of Mormon land ownership in the county.

17. Kimball, "Nauvoo West," 135. The site of Old Fort Des Moines is located in Montrose at Riverfront Park's south end next to the railroad tracks, and is identified by a bronze plaque noting the site of a well that served the old fort.

18. Donna Hill, Joseph Smith, The First Mormon (New York, 1977), 268-69.

19. Maurine Carr Ward, "The Mormon Settlement at Nashville, Lee County, Iowa: One of the Satellite Settlements of Nauvoo," Nauvoo Journal 8 (1996), 10.

20. In the LDS church organizational framework, local congregations then were termed branches (now most are called wards), and 6 to 12 branches were supervised by a stake, administered by a 3-man stake presidency and a 12-man high council. Each branch had a president who presided over its members and meetings. LDS stakes were supervised by General Authorities of the church, which then were the First Presidency (the LDS prophet and his two counselors) and the Quorum of Twelve Apostles. 
encouraged to move into Nauvoo. Many stayed, however, and continued to develop the area. ${ }^{21}$

In addition to Montrose, Mormons founded four other Iowa settlements: Zarahemla, Ambrosia, Nashville, and Augusta. Zarahemla, established on Montrose's west side, a mile from the river, had about 30 houses at its peak. The Zarahemla congregation included Mormons from Montrose, so by 1841 it was the largest LDS unit in Iowa, with 326 members. ${ }^{22}$

By the summer of 1839, Saints had settled in Ambrosia, which was three miles west of Montrose and extended another four miles westward. At first it was called Hawley's Settlement. Ultimately, about one hundred Mormons lived there. When the first wave of Mormons left Nauvoo in 1846, their massive Sugar Creek encampment was located within the Ambrosia settlement area. $^{23}$

On the 20,000 acres south of present Montrose that the LDS church bought in 1839, the Mormons founded a town they named Nashville. Members were organized into a church unit called a branch, had a large stone building for public worship, and provided a steamboat landing on the river. "We have a good market here," Elias Smith wrote in August 1841, "as it is the first landing for Steam Boats" above the rapids. In low wa-

21. Andrew Jenson, "Zarahemla," Encyclopedic History of The Church of Jesus Christ of Latter-day Saints (Salt Lake City, 1941), 971. Two traditional Mormon stories connect Mormon founder Joseph Smith with Montrose. According to one story, when a group of Mormons founded The Rising Sun Masonic Lodge in Montrose in August 1842, Joseph Smith prophesied that the Latter-day Saints would be driven to the Rocky Mountains and become a mighty people there. Later, four days before Smith was killed, he crossed to Montrose and considered escaping to the West, but then returned to Nauvoo and his death. Joseph Smith Jr., et al., History of the Church of Jesus Christ of Latter-day Saints, 6 vols., ed. B. H. Roberts, 2 d ed., rev. (Salt Lake City, 1951), 5:85, 6:548-49. That Joseph Smith predicted the Saints would move to the Rocky Mountains is well documented. The claim that he received that "Rocky Mountain Prophecy" at Montrose comes from Anson Call, who recalled the event many years later. See Paul Thomas Smith, Prophetic Destiny: The Saints in the Rocky Mountains (American Fork, UT, 1996).

22. Smith, History of the Church, 6:548-49. See fn. 20 above for a definition of an LDS branch.

23. According to Kimball, "Nauvoo West," 139, the Ambrosia site was marked in 1978 by a cluster of later homes three miles west of the Montrose city limits on county road J72, "locally known as Ambrosia Lane." 
ter, he added, "boats receive and discharge their freight at this place ... within a few rods of our door." As they left Nauvoo in May 1846, many Saints crossed to Nashville. ${ }^{24}$

In Augusta, eleven miles northeast of Fort Madison and sixteen miles from Nauvoo, a sizable Mormon population clustered on both sides of the Skunk River, those on the north side in Des Moines County, those on the south side in Lee County. Among Augusta's founding settlers who converted to Mormonism were Fredrick Kesler, who surveyed the Augusta town site in 1835, and Levi Moffitt, who built Iowa's first water-powered flour mill there in 1835. Converts were joined by several Mormon families who fled Missouri in 1838-39, causing a new township to be surveyed south of the Skunk River. By late summer the branch had 50 members. By the time James Brown was made branch president on April 1, 1843, the branch had 84 members. And when LDS President Joseph Smith conducted a church conference in Augusta on April 30, 1843, about 200 Mormons attended. According to Smith's history, Augusta was then a "flourishing town" with three saw mills and two flour mills. An organized branch of the LDS Church continued there until 1844, when rising animosities forced members to move to Nauvoo. ${ }^{25}$

Given the significant presence of Mormons in and around Lee County in the 1840s (small numbers of Mormons lived in Lee County locations other than those mentioned here as well as in counties contiguous to Lee County ${ }^{26}$ ), historians could en-

24. Ward, "Mormon Settlement at Nashville"; Smith, History of the Church, 3:345 and 4:182n; Nauvoo Times and Seasons, September 1840; Elias Smith to Jesse Smith, 31 August 1841, quoted in Ward, "Mormon Settlement at Nashville," 12; Journal History, 22 May 1846, 2. Since 1913, water backed up by the Keokuk Dam has inundated much of the Nashville site.

25. Nauvoo Times and Seasons, 15 January and 15 September 1841; Smith, History of the Church, 5:371. On 10 January 1841, while Joseph Smith attended a church meeting in Augusta, someone cut off the tails, manes, and an ear from two of his horses. Smith, History of the Church, 5:318.

26. According to Kimball, "Nauvoo West," 136, Mormons owned land in Chequest and Van Buren Townships in Van Buren County. In a forthcoming biography of Mormon convert Lewis Barney (copy in author's files), descendant Ronald Barney identifies several Iowa LDS branches Kimball did not list, including ones at Fort Madison and West Point in Lee County and his ancestors' branch of some 30 members in Henry County where Wayland now is. 
hance the understanding of early days in that county, particularly in Montrose and its vicinity, by examining county land records, LDS church records in Utah, and personal records of Mormons who lived there before they moved west.

Connection 3: The Emmett Company Expedition (1844-1846). In August and September 1844, James Emmett, responding to an exploring and colonizing assignment given to him by Joseph Smith just weeks before Smith's death, led more than 150 Saints from the Nauvoo area into Iowa Territory. ${ }^{27}$ Emmett's recruits left the Nauvoo area, crossed the Mississippi, and reached Iowa City-some from Fort Madison by roads and some by boat up the Mississippi and part way up the Iowa River, then heading overland. Once assembled in Iowa City, they moved 30 miles up the Iowa River and encamped at the site where Marengo is now. Early in 1845 they moved up along the Iowa River and camped eight miles northwest of Marshalltown. "Mormon Ridge," named for that encampment, is a Marshall County landmark. ${ }^{28}$

A "Mystery of Mormon Ridge" circulates as folklore in the county. It tells of a phantom Mormon company that wintered on the ridge. Many of the Mormons supposedly died and were buried in the area. According to the story, government wagons rescued survivors, including a pregnant woman who gave birth on the way to Iowa City. The story seems to be a tangled mix-

27. This section is based on my history of the James Emmett Expedition, in My Best for the Kingdom: History and Autobiography of John Lowe Butler, a Mormon Frontiersman (Salt Lake City, 1993), chaps. 12, 13, 14, and 16, which revises earlier historians' interpretations. Heman C. Smith published an incomplete and misinterpreted hisțory of the Emmett Expedition in his "Pioneer Trails Across Iowa," in the RLDS church's Journal of History 10 (1917), 39-42. Essential is Dale L. Morgan, ed., "Reminiscences of James Holt: A Narrative of the Emmett Company," Utah Historical Quarterly 23 (1955), 1-33, 151-79. Gerald E. Jones, "An Early Mormon Settlement in South Dakota," South Dakota History 1 (1971), 119-31, is a modest study; Richard E. Bennett, "Mormon Renegade: James Emmett at the Vermillion, 1846," South Dakota History 15 (1985), 217-33, is overly critical of Emmett and those with him.

28. Mormon Ridge is reached by driving 5 miles west of the south end of Marshalltown on US Highway 30, 5 miles north on County Road S75 to County E29, 5 miles west on County E29, and 4.2 miles north on County S62 to County E23. At that point the ridge is visible to the east. Travel $1 / 2$-mile east on E23 to where it intersects Mormon Ridge Road. 
ture of Mormon happenings locals had heard smatterings about-LDS deaths at Winter Quarters in 1846-47 and LDS handcart companies that passed through Iowa in 1856 and suffered deaths during Wyoming blizzards-combined with the Emmett Company's experiences. ${ }^{29}$

What is factually certain is that from mid-February to April 1845 the Emmett Company camped at the southeastern tip of this ridge near where Minerva Creek flows into the Iowa River. ${ }^{30}$ These Saints built rude huts or cabins and tapped maple trees for sugar. Five leaders were arrested by a posse from Iowa City on charges of stealing, taken to the capital, and then released when their accusers failed to show up. About one-third of the Emmett Company became disaffected and returned to Nauvoo. In early May the expedition, reduced to 22 wagons, continued northward and then west-northwest across Iowa. On June 7, 1845, they reached the Missouri River near present Burbank, South Dakota, and established Camp Vermillion, where they wintered.

Almost a year later, in March 1846, Brigham Young's company of Nauvoo exiles (see connection 4 below) was at the Chariton River Camp. There, Young ordered John Lowe Butler and James W. Cummings to push ahead to the Missouri, then go upriver to bring the Emmett Company down to the Council Bluffs area to join Young's company. Butler's family was at Camp Vermillion, where he had been second in command until called back to Nauvoo late in 1845, and he was anxious to retrieve them. On March 30, Butler and Cummings started their journey from

29. Gretchen I. Sipes became Marshalltown's expert and earnest detective on the Mormon Ridge mystery. In the 1950s she believed that the Mormon group was the Emmett Company, but after struggling to incorporate all the local lore into the story, she decided she must find a Mormon emigrant group unknown thus far in history records. She kindly gave me copies of her file materials, including her short typed discussion, "The Legends of Mormon Ridge"; her 1950s account called "The Story of Mormon Ridge"; her "Mormon Ridge Mystery" in the Marshalltown Times-Republican, 9 February 1988; Mrs. Wesley Halladay's recollections in "Experiences of Mormon Visitors in 1850-51 Recalled by Pioneer," ibid., 3 November 1927; and "Band of Starving Mormons Wintered in County Before City Was Born," in ibid., centennial issue, June/July 1953. Sipes died in 1999.

30. The campsite is in the SE part of the SE $1 / 4$ of section 34, Bangor Twp. (R19W T84N). 
the Chariton River (near present-day Centerville) over uncharted prairie, without a map or compass. On April 14 they reached the Potawatomi village by the Nishnabotna River (near presentday Lewis in Cass County), seven weeks ahead of Brigham Young. Arriving at the Missouri two days later (at present Council Bluffs), they found to their surprise seven Camp Vermillion families who had been led there a month earlier by Lyman Hinman. Butler and Cummings instructed the group to move south to the Missouri state line, where they could find work while waiting for Brigham Young's company."

On April 19, Butler and Cummings started for Camp Vermillion, going north along the Missouri River's eastern shore. Lacking a trail, they had to find their own way. With difficulty they crossed Pigeon Creek, the Boyer River, Soldier Creek, the Little Sioux River, Willow Creek (where Sioux City is now), and the Big Sioux River near its mouth. After an arduous eight-day trip covering some 130 miles, they reached Camp Vermillion.

On May 5, Butler and Cummings headed the Emmett Company south, trying to follow the slight trail they had made on the way up. Their caravan included 14 wagons, 12 families, and 59 people. On May 29 they camped just below Traders Point, on Mosquito Creek. After some trading, they moved south to be near the Missouri border, camping near present-day Hamburg. In late June they moved back up to Traders Point, where they met and merged with Young's advance teams, ending their 22month expedition experience.

The Emmett Company's journey across Iowa from southeast to northwest left its mark on local lore in Iowa City, Marengo, and Marshalltown. James Cummings's diary provides historically useful geographic details about southwestern Iowa and about Iowa's "west coast" in Pottawattamie, Harrison, Monona, Woodbury, and Plymouth Counties.

Connection 4: The Three-stage Mormon Exodus from Nauvoo (1846). The Latter-day Saints' epic evacuation from Nauvoo, Illinois, in 1846 can be compared to a three-act play. Some 15,000

31. Cummings's diary account of the trip is in Hartley, My Best for the Kingdom, 187-208. 
Saints departed, not in one mass exodus led by Brigham Young, but in three separate waves of departures-in winter, spring, and fall $(1,000$ to 2,000 others left Nauvoo but did not go to Utah). ${ }^{32}$ History books concentrate on the smaller, winter exodus of Brigham Young's advance company, which called itself the "Camp of Israel," rather than the much larger spring exodus because (1) it was the first wave of people who left Nauvoo en masse and who pioneered routes and travel methods; (2) it contained the church's top leaders, including most of the Twelve Apostles; (3) it was an organized (much of the time) caravan that shared a collective, common history; and (4) its experiences were well recorded. The Camp of Israel's historic route through Iowa is the Iowa segment of what the federal government officially designated in the 1970s as the 1,300-mile Mormon Pioneer National Historic Trail. ${ }^{33}$ Although it is the bestknown and best-understood Mormon connection with Iowa, accounts of it often contain some errors and misconceptions.

The winter exodus began in February 1846, but, contrary to some popular versions, hardly anyone crossed the Mississippi River from Nauvoo on ice. This wave of people left ahead of the intended spring schedule because of rumors and threats that federal troops planned to block the Saints' departures, or that Illinois officials might arrest church leaders. ${ }^{34}$ Leaders decided that they

32. Published histories offer widely differing population estimates, some claiming 20,000 or more. The most reliable contemporary records of departures from Nauvoo put the figure at about 15,000. Nauvoo itself, as noted earlier, peaked at about 12,000 people. Of the 17,000 or so in the larger region, I estimate that approximately 14,000 departed who were loyal to Brigham Young, and that another 1,000 to 2,000 disavowed Young's leadership and went their separate ways. Among the latter were Joseph Smith's mother, Lucy, and his wife, Emma. Emma's family provided the core for the Reorganized Church of Jesus Christ of Latter-day Saints (see the introduction and connection 8.)

33. Stanley B. Kimball, Historic Resource Study: Mormon Pioneer National Historic Trail (Washington, DC, 1991). Carol Cornwall Madsen, Journey to Zion: Voices from the Mormon Trail (Salt Lake City, 1997), 13-303, contains 16 first-person accounts by Mormons on the Iowa Mormon Trail in 1846.

34. A reasonably good but dated summary of the Winter Exodus is William J. Petersen, "The Mormon Trail of 1846," Palimpsest 47 (1966), 353-67. Booklength accounts include Preston Nibley's excellent but dated Exodus to Greatness: The Story of the Mormon Migraton (Salt Lake City, 1947); Wallace Stegner's exciting and insightful classic, The Gathering of Zion: The Story of the Mormon Trail (New York, 1971); and Richard E. Bennett's award-winning Mormons at 
must leave, and they invited all who were properly outfitted to go with them. On February 4, Charles Shumway ferried across the Mississippi River, starting the pullout. For three weeks, as temperatures fell, wagons ferried across, often dodging ice. The designated assembly place, seven miles inland along Sugar Creek, became an ever-expanding campground. By mid-February those in Sugar Creek Camp were suffering from freezing temperatures and snow. Campfires burned constantly. After Charles C. Rich walked across the river on ice on February 25, several dozen wagons crossed the ice bridge during the next few days. ${ }^{35}$

The church's apostles, with Senior Apostle Brigham Young in charge, headed this initial migration of about 500 wagons and 3,000 people. ${ }^{36}$ Included were such LDS notables as Apostles Heber C. Kimball, Willard Richards, Orson Pratt, and Parley P. Pratt and General Bishops Newel K. Whitney and George Miller. Diarists in the company included William Clayton, Eliza Snow, Willard Richards, Hosea Stout, Horace K. Whitney, John Smith, John Lee, and Patty Sessions. The entire group was subdivided into five companies of 100 wagons each, then into subcompanies of fifty and ten, with captains over each unit. Brigham Young sent Bishop George Miller ahead with the "Pioneer Company" to improve roads and bridges, locate campsites, and collect firewood.

the Missouri, 1846-1852 (Norman, OK, 1987). General LDS histories that discuss the exodus in reasonable detail include Russell R. Rich, Ensign to the Nations: A History of the Church from 1846 to the Present (Provo, UT, 1979); Allen and Leonard, Story of the Latter-day Saints; and Brigham H. Roberts, A Comprehensive History of the Church of Jesus Christ of Latter-day Saints, 6 vols. (Salt Lake City, 1930), vol. 2. A special issue of Brigham Young University Studies 21 (Fall 1981 ) is devoted to Mormons in Iowa. David R. Crockett provides a day-byday account through diary and document excerpts in his Saints in Exile: A Dayby-Day Pioneer Experience, Nauvoo to Council Bluffs (Tucson, AZ, 1996).

35. Some accounts say several hundred wagons crossed on the ice; reasonable estimates range from a few dozen to as many as 200. Donna Toland Smart, ed., Mormon Midwife: The 1846-1888 Diaries of Patty Bartlett Sessions (Logan, UT, 1997), 35; Elden J. Watson, comp., Manuscript History of Brigham Young (Salt Lake City, 1971), 50, entry for 25 February 1846.

36. Brigham Young estimated 500 wagons (families) in the Camp of Israel on March 1, with some 300 single men serving as pioneers, guards, or artillerymen. On March 9 Horace K. Whitney said the camp number "somewhat exceeds 2,000." When the camp reorganized at the Chariton River on March 27, six companies of fifty were formed-300 to 400 wagons (families) or 1,800 to 2,400 people. 
On March 1 the large Camp of Israel company began its three-and-a-half-month trek to the Missouri River, about 300 miles away. ${ }^{37}$ On day five, at the village of Bonaparte, they forded the Des Moines River. The companies made an extended stop (March 7-18) at Richardson's Point, 22 miles west of Bonaparte. While there, William Huntington said, men found work "such as building houses Chopping timber splitting rails husking corn. ${ }^{\prime 38}$ Meanwhile, Captain William Pitt's Nauvoo Band presented concerts for pay at Farmington's Galt House and schoolhouse on March 4, and in Keosauqua's Van Buren County Courthouse (which is still operating) on March 10, 11, and 17, followed by a private concert in Keosauqua's hotel, also on March $17 .^{39}$

37. A quick and readable 28-page guide outlining the Mormons' routes across Iowa in 1846 is Explore Iowa's Historic Mormon Trails, published by the Iowa Mormon Trails Association in 1997; the standard site guide is Kimball, Historic Sites and Markers. Kimball's "The Iowa Trek of 1846" in the LDS monthly magazine, Ensign (June 1972), 36-45, provides a camp-by-camp chronology and description of the Camp of Israel's Winter Exodus trek across Iowa. Published diaries by Winter Exodus participants are Brigham Young's Manuscript History, Diary of Hosea Stout, and Patty Sessions's Diaries; Clayton Family Organization, William Clayton's Journal (Salt Lake City, 1921); "Eliza Partridge Lyman Journal," in Melvin A. Lyman, comp., Amasa Mason Lyman Family History, Vol. II (Delta, UT, 1969), 13-38; Elden J. Watson, comp., The Orson Pratt Journals (Salt Lake City, 1975); Maureen Ursenbach Beecher, ed., "The Iowa Journal of Lorenzo Snow," Brigham Young University Studies 24 (1984), 261-73; Jeni Broberg Holzapfel and Richard Neitzel Holzapfel, eds. A Woman's View: Helen Mar Whitney's and Reminiscences of Early Church History (Provo, UT, 1997); and "Diary of Lorenzo Dow Young," Utah Historical Quarterly 14 (1946), 132-70. Unpublished diaries and autobiographies in the LDS Church Archives in Salt Lake City include those by James Willard Cummings, Mosiah Hancock, Willard Richards, John Smith, Eliza R. Snow, Horace K. Whitney, and George Whittaker. William Huntington's diary is in Special Collections, Lee Library, Brigham Young University, Provo, Utah.

38. Diaries of William Huntington, typescript, entry for 8 March 1846, p. 48, Brigham Young University Library.

39. William Clayton's Journal, entries for 4, 10, 11, and 17 March 1846, pp. 5-7. The Nauvoo Brass Band started in 1842, directed by Englishman William Pitt (born 1813). During the Winter Exodus, 15 members of the band traveled together in two companies of ten, and entertained the Saints. They performed as both a brass band and, by adding strings and wind instruments, a quadrille band (the quadrille band provided the Keosauqua concert on the 17th). John Kay, a "magnificent baritone," was their main vocalist. The band's journal kept during the trek west is excerpted in an LDS magazine published in Utah a century ago; see "An Interesting Record," The Contributor 1 (June 1880), 195-98, and "The Nauvoo Brass Band," ibid. (March 1880), 134-37. 
Moving northwest along the Fox River in cold weather, the companies passed just north of Bloomfield. Leaving this last settlement that they would find in Iowa, they headed southwest to skirt the Missouri border in order to trade with Missourians for feed and food. Their plan was to cross the Missouri River not at the Council Bluffs but at Banks Ferry in Missouri, north of St. Joseph. ${ }^{40}$ Turning sharply south at present-day Drakesville, they soon came upon the Old Mormon Trace, blazed in 1838 by Mormons fleeing Missouri (see connection 1 above).

March's snow, cold, rain, and awful mud made the trek miserable and exhausting. At the difficult Chariton River crossing, they double-teamed the wagons to descend and ascend the muddy banks. They stayed in their mud-plagued Chariton Camp (south of present Centerville) for more than a week, from March 22 to $31 .^{41}$ President Young recorded that late March storms and cold caused "severe colds" among the campers. While encamped, President Young regrouped the wagons, now totaling only 400, into six better structured "companies of fifty" (though there were more than fifty in some companies). ${ }^{42}$

Restarting the caravan on April 1, they exited the last organized county through which they would pass, although they still followed rudimentary roads. Their progress was slow, hampered by rain and knee-deep mud. On April 6-15, the companies camped by Locust Creek, three miles above today's Missouri border, in what became Wayne County. ${ }^{43}$ On April 15, Englishman William Clayton, excited by news from Nauvoo of

40. Diary of Hosea Stout, 2 April 1846.

41. Appanoose County is the most thoroughly researched county through which the 1,300-mile Mormon Trail ran, because of Heusinkveld's thorough 79-page guide and study, Mormon Trails Across Appanoose County, Iowa.

42. Eliza R. Snow Diary; Brigham Young, Manuscript History, 108-9, 118 (27 and 31 March 1846).

43. Even making allowance for the disputed Missouri border line at the time, some 1846 diaries say they were in Missouri, not in the disputed section in Iowa. Also, diary tallies of daily miles traveled from the Chariton River to Garden Grove require a longer route than what is now marked as the Mormon Pioneer National Historic Trail through Appanoose and Wayne Counties. That the company decided at Locust Creek Camp to turn from westbound to head northwest makes no sense if decided at the presently identified location, because to get there they would have already made such a north turn from their westbound course in order to be at that site. 
the birth of his son, wrote celebratory words to sing to an English song, "All Is Well." His song became the Mormon pioneer anthem, "Come Come Ye Saints," so the campsite has special significance to Mormons and is memorialized by a historic marker at the Tharp Cemetery, three miles south of Seymour. ${ }^{44}$ Meanwhile, ever since the group had encamped at Richardson's Point, Mormon traders regularly ventured south into Missouri to trade at farms and hamlets.

At the Locust Creek Camp, leaders decided against continuing westward. Instead, they headed northwest toward a Missouri River crossing at "the Council Bluffs." By mid-April, prairie grasses began sprouting. From April 24 to May 12 the Mormons made an extended stop by the Weldon Fork River's headwaters (about 50 miles due south of Des Moines). There they established a temporary settlement, Garden Grove, to provide homes and farm produce for those unable to keep going and for others soon to arrive from Nauvoo. ${ }^{45}$ Later, about 600 Mormons wintered at Garden Grove; about 70 died from exposure and diseases linked to malnutrition. Today, historic markers designate the settlement site and cemetery (which are less than a mile west of present-day Garden Grove). Garden Grove continued as a Mormon settlement until 1851.

Leaving some members at Garden Grove, Young's company pushed northwest to the Grand River and established a second temporary settlement, Mt. Pisgah. (The location, marked today by a park, an obelisk monument, and historical markers, is 40 miles southwest of Des Moines and 20 miles west of Osceola.) Church apostle Parley P. Pratt picked the site and named it Mt. Pisgah because when he first viewed its dramatic overlook of the Grand River Valley he compared it to Moses viewing the Promised Land from the summit of Mt. Pisgah (Deut. 3:27).

44. William Clayton's Journal, 19 (15 April 1846). At Corydon the Prairie Trails Museum of Wayne County has an impressive display devoted to the Iowa Mormon Trail and to "The Hymn That Went Around the World."

45. Leland H. Gentry, "The Mormon Way Stations: Garden Grove and Mount Pisgah," Brigham Young University Studies 21 (1981), 445-61; Karla Gunzenhauser, "The Settlement at Garden Grove, Iowa," Nauvoo Journal 6 (1994), 14-44; Lynn Robert Webb, "The Contributions of the Temporary Settlements Garden Grove, Mount Pisgah, and Kanesville, Iowa, to Mormon Emigration, 1846-1852" (master's thesis, Brigham Young University, 1954). 
Young's company stayed there from May 18 to June 1, building cabins, plowing farms, and erecting fences before they resumed their journey. ${ }^{46}$ Several hundred Mormons wintered there; like those at Garden Grove, they suffered from a high death toll. And, like Garden Grove, Mt. Pisgah continued to be a Mormon stopover settlement until it closed down by 1852 .

After leaving hundreds at Garden Grove and Mt. Pisgah, the Camp of Israel resumed its journey on June 1, 1846. By then new arrivals from the Spring Exodus constantly added to its numbers. After passing the Potawatomi village west of presentday Lewis on June 8, they encountered several rugged streams they had to bridge. Finally, on June 13 the lead wagons halted in view of the Missouri River at present-day Council Bluffs, completing their journey across Iowa three-and-a-half months after starting from Sugar Creek Camp near Montrose. Even though rain and cold weather took their toll on the travelers during the long journey, very few deaths occurred along the way-contrary to some popular tellings of the Winter Exodus story.

In subsequent weeks, successive wagon companies arrived from Nauvoo and camped next to the previous arrivals, creating a "Grand Encampment" stretching about nine miles eastward from President Young's camp (from today's Iowa School for the Deaf to present Treynor). ${ }^{47}$ Unable to cross the Missouri River, the companies waited while workmen built a ferryboat. Ferrying commenced July 1.

While they waited, federal recruiters arrived from Fort Leavenworth, enlisted some 500 Mormon men (about onefourth of the Mormons' capable manpower) into a Mormon Battalion to serve in the Mexican War, and led them off to Fort Leavenworth. The battalion, part of Colonel Stephen W. Kearny's Army of the West, performed one of the longest infantry marches in U.S. military history, about 2,000 miles, from Fort Leavenworth to Santa Fe to San Diego, where they arrived in January 1847. Under Lt. Col. Philip St. George Cooke they opened up the first wagon route across the Southwest. Mustered out of service in

46. Andrew Jenson, "Mount Pisgah," Utah Genealogical and Historical Magazine 7 (1916), 157-75; Gentry, "Mormon Way Stations."

47. The term Grand Encampment appears in Diary of Hosea Stout, 5 July 1846. 
Los Angeles in July 1847, many of the men crossed the Sierras and made the long journey back to the Council Bluffs area by December 1847 to rejoin their families. ${ }^{48}$

The dramatic story of the Winter Exodus dominates the historical memory of the 1846 Mormon Trek across Iowa. Yet only one-fourth of the Saints who left Nauvoo in 1846 were in Brigham Young's winter company. At least two-thirds left according to the original plan, in springtime, when "grass grows and water runs. ${ }^{\prime \prime 9}$ In the three months after hundreds of Mormons attended the public dedication of the Nauvoo Temple on May 1, some 10,000 people, including two apostles-Wilford Woodruff and Orson Hyde - and several prominent families, left Nauvoo, intent on catching up with Brigham Young's company. ${ }^{50}$

On May 14, Illinois Governor Thomas Ford reported that 50 teams and 1,350 individuals had left Nauvoo that week. ${ }^{51}$ A week later, on May 22, the Bloomington Herald noted that ferries, running day and night, crossed the Mississippi River 35 times in 24 hours at Nauvoo, 35 times upriver at Fort Madison, Iowa,

48. On the Mormon Battalion, whose official name was the First Volunteer Infantry of Iowa Territory, see Daniel Tyler, A Concise History of the Mormon Battalion in the Mexican War, 1846-1847 (1881; reprint, Glorieta, NM, 1988); John F. Yurtinus, "A Ram in the Thicket: The Mormon Battalion in the Mexican War" (Ph.D. diss., Brigham Young University, 1975); Norma Ricketts, The Mormon Battalion: U.S. Army of the West, 1846-1848 (Logan, UT, 1996); Larry C. Porter, "Interrupted Exodus: Enlisting the Mormon Battalion as Iowa Volunteers," in Black and Hartley, eds., Iowa Mormon Trail, 133-54.

49. William G. Hartley, "Spring Exodus from Nauvoo: Act Two in the 1846 Mormon Evacuation Drama," in Black and Hartley, eds., Iowa Mormon Trail, 61-84, identifies source materials dealing with the Spring Exodus and provides full citations (which are not provided here). The most useful diary accounts are those of Newel Knight, Samuel W. Richards, Joseph Holbrook, Lucius Scovil, Wilford Woodruff, Mary Haskin Parker Richards, and Louisa Barnes Pratt. The last three have been published. Also useful are published biographies of James S. Brown, Edwin D. Woolley, Archibald Gardner, and Robert T. Burton, and life writings related to Lewis Barney, Anson Call, Mosiah Hancock, Isaac Haight, Orson Hyde, and Abraham O. Smoot. Several first-person accounts in Madsen's Journey to Zion relate to the Spring Exodus.

50. Elder Hyde reached Mt. Pisgah by June 7, Woodruff on June 15. See Orson Pratt Journals, 7 June 1846; Scott G. Kenney, ed., Wilford Woodruff's Journal, vol. 3 (Midvale, UT, 1983), 15 June 1846.

51. William E. Berrett, The Restored Church: A Brief History of the Growth and Doctrines of the Church of Jesus Christ of Latter-day Saints (1936; reprint, Salt Lake City, 1961), 226. 
and several times downriver at Nashville, Iowa. Between Montrose and the mouth of the Des Moines River, the newspaper added, teams numbered about 1,400 , with perhaps 7,000 to 8,000 persons, and "the slopes of the hills and the prairie opposite Nauvoo, are still dotted with clusters of tents and wagons. ${ }^{\prime \prime 2}$

Unlike the Camp of Israel, no superior captains directed the spring waves of departures. As John Woolley put it, "as soon as a few families got ready they would start." ${ }^{\prime 53}$ Few companies had more than 30 wagons. Most contained a dozen or less. James S. Brown, while observing Mormon covered wagons "as far as the eye could reach" about May 10, noted that "the teams were made up of oxen, milch cows, two-year-old steers and heifers, and very few horses and mules." Drivers, he said, "were of both sexes, and comprised young and old." People who could walk, did so, he said, "and many were engaged in driving loose stock. ${ }^{\prime 54}$

Spring grasses provided feed for the livestock, so the spring groups had no need to travel near the Missouri settlements to trade for feed. Instead, they favored better, more northern roads and routes, and crossed Iowa in only a month. Most followed the Camp of Israel's route only as far as present-day Drakesville. Many passed through Bonaparte - on May 29, forty teams backed up at the Bonaparte Ferry, causing long delays. ${ }^{55}$ Just west of Drakesville, the spring groups left Brigham Young's route where it turned south; instead, they went west and northwest on the "Alternate Mormon Trail." This route went to present Unionville, then turned north and crossed South Soap Creek, continued northward to present Moravia, and then ran west to present Iconium. Just west of there the route split. The left or south branch went to Garden Grove. The right or northern branch headed to present-day Chariton, following high ground between the Chariton River and White Breast Creek through present-day Lucas and Clarke Counties and then intercepting

52. Bloomington Herald, 22 May 1846.

53. Leonard J. Arrington, From Quaker to Latter-day Saint: Bishop Edwin D. Woolley (Salt Lake City, 1976), 33.

54. James S. Brown, Giant of the Lord: Life of a Pioneer (Salt Lake City, 1960), 32.

55. Journal of Lucius N. Scovil, microfilm of holograph, LDS Church Archives. 
the Camp of Israel's trail again about six miles south of where Osceola now is. These "alternate trails" actually bore more Mormon traffic than did the more famous winter route that is now an official historic trail. ${ }^{56}$ Other Mormons left Montrose and Fort Madison not on the Mormon Trail route but, instead, headed northwest and crossed the Des Moines River higher up-at Iowaville, Eddyville, or near present-day Des Moines.

Spring travel accounts agree that the Mormons used existing roads, which were in poor shape and became ribbons of mud when it rained. Spring traffic was heavy. Sometimes, Newel Knight noted, the prairies were "spotted with waggons Cattle horses \& Sheep Men Women \& Children." James S. Brown said he encountered campers "at every creek." Because the spring groups constantly passed pools of rainwater, they often suffered illnesses-some of them fatal-that were spread by mosquitoes. ${ }^{57}$

Several Camp of Israel diarists noted when Spring Exodus Saints caught up with them. Perhaps envious, Patty Sessions wrote on May 15, a few miles beyond Garden Grove, "Some from Nauvoo overtake us they have been on the road but 3 weeks we 3 months. ${ }^{\prime \prime 58}$ Early in July Brigham Young counted 1,805 wagons between his Missouri River camp and Mt. Pisgah-1,300 more than his Camp of Israel started with-and hundreds more were still east of Mt. Pisgah. ${ }^{59}$ By the end of July, most of the Spring Exodus groups had caught up with Brigham Young's company and merged with it near the Missouri River.

The final departures from Nauvoo-the Fall Exodus-occurred in September 1846 when armed mobs drove the remaining few hundred Saints from Nauvoo, although most of them were too ill or unequipped for the trek. A mid-September count

56. For maps and discussions of the alternate routes, see Kimball, Historic Sites and Markers, chaps. 3 (Variant A) and 4 (Variant B); idem, "The Mormon Trail Network in Iowa, 1838-63: A New Look," Brigham Young University Studies 21 (1981), 417-30; and idem, "From Nauvoo to Council Bluffs" explanation and map in Historical Atlas of Mormonism, 70-71.

57. Newel Knight Journal, 11 May 1846; Brown, Giant of the Lord, 33; Wilford Woodruff's Journal, vol. 3, Spring 1846 entries.

58. Patty Sessions, Diaries, 15 May 1846.

59. Brigham Young, Manuscript History, 7 July 1846. 
found between 600 and 700 Saints camped by Potter's Slough on the Mississippi River's west side about a mile north of Montrose, waiting for help or hoping to recover. Many had moved out by the time diarist Thomas Bullock counted 17 tents and 8 wagons in camp on October 4. "Most of those are the poorest of the Saints," he said; "not a tent or wagon but sickness in it, and nearly all don't know which [way] they shall get to the main camp. ${ }^{\prime \prime 60}$ At least two LDS rescue wagon trains from western Iowa retrieved half of these forlorn people. The others departed on their own.

While they waited, Saints in the so-called Poor Camps experienced what Mormons call the "Miracle of the Quail" on October 9. Large flocks of exhausted quail flopped into the camp, landing on and under wagons and in tents. "Every man, woman and child had quails to eat for their dinner," Thomas Bullock wrote. The Saints interpreted their appearance as divine aid. ${ }^{61}$

While most Mormon refugees crossed most of Iowa in 1846, scores took up temporary work and lodging in eastern Iowa. Sick Jonathan Crosby borrowed oxen for his teamless wagon, moved to Bonaparte, worked to earn two yoke of oxen, and headed west the next spring. Wendle Mace moved his sick wife into a house in Keosauqua, worked as a mechanic for the flour mill, built several saw and grist mills in the area, and headed west in 1848. Albert and Tamma Durfee Miner left the Poor Camps and lived in Iowaville for two seasons. After Albert died there in 1848, Tamma took her children west. Asahel Smith, uncle of Mormon prophet Joseph Smith, and his family also stayed in Iowaville, where both Asahel and his wife, Elizabeth, died and are buried. ${ }^{62}$

60. Will Bagley, ed., The Pioneer Camp of the Saints: The 1846 and 1847 Mormon Trail Journals of Thomas Bullock (Spokane, WA, 1997), 72. Potter's Slough is now covered by the Mississippi River.

61. Journals of Thomas Bullock, 9 October 1846, p. 76; Richard E. Bennett, "'Dadda, I Wish We Were Out of This Country': The Nauvoo Poor Camps in Iowa, Fall 1846," in Iowa Mormon Trail, 155-70; idem, "Eastward to Eden: The Nauvoo Rescue Missions," Dialogue: A Journal of Mormon Thought 19 (1986), 100-108.

62. Jonathan Crosby Autobiography, typescript, LDS Church Archives, 26-28; Autobiography of Wendle Mace, 1809-1890, typescript, LDS Church Archives, 194-211; William G. Hartley, "Latter-day Saints at Iowaville, Iowa, 1846-1851," Nauvoo Journal 7 (1995), 38-43. 
Of some 14,000 Saints who left the Nauvoo area for the west in 1846, a reasonable estimate is that between 2,000 and 3,000 lagged behind, halting temporarily in southeastern Iowa or northern Missouri. Lacking food, funds, good wagons and teams, or decent health, many sought housing and jobs, and did not reach the LDS camps at the Missouri River for months or even years. These people are the sources of such "imprints" in southeastern Iowa as Mormon Creek east-northeast of Moravia, Bentonsport's Mason House Inn (whose sign in front says it was built by Mormon workmen in 1846), reputed Mormon graves in Louisa County, and others too numerous to list. ${ }^{63}$

\section{Connection 5: Kanesville (early Council Bluffs), LDS Hub and} Outfitting City (1846-1852). From the time the first Nauvoo refugees reached the Missouri River where Council Bluffs now is until 1852, Mormons were the dominant presence in southwestern Iowa. The area that extends 60 miles north, east, and south from Council Bluffs is rich in sites and history relating to LDS history. (Originally "Council Bluffs" was the name the Lewis and Clark Expedition attached to bluffs 20 miles upstream on the Missouri River's west side, but by 1846 the name was associated with the general region from there down to today's Council Bluffs.) By June 13, 1846, Brigham Young's advance parties had reached the Missouri River, followed during subsequent weeks by thousands more LDS refugees. Three miles away, at Traders or Trading Point (Point-Aux-Poules), the Mormons interacted frequently with Peter Sarpy's American Fur Company trading houses and with U.S. Indian agent Robert B. Mitchell. ${ }^{64}$

By August 1846, the Mormons had given up their plans to reach the Rocky Mountains that year. After that, the concentration of refugees started to fan out. Within two months, half established Winter Quarters on the west side of the Missouri River, where Florence, Nebraska, now is, and half scattered up and

63. For the Mormon graves in Louisa County, see "Smith/Mormon Cemetery of Eliot Township ....'" in Maxine Bennett, comp., Cemeteries of Louisa County, Iowa (Wapello, IA, 1990), E-26, 27.

64. Brigham Young, Manuscript History, June and July 1846 entries, note frequent contacts LDS leaders had with Sarpy, Mitchell, and the trading post. 
down the Iowa side, settling at dozens of sites by streams and near timber. In what is now Council Bluffs, Henry W. Miller's camp became known as Miller's Hollow. Miller acted as a Mormon bishop there and later was the area's delegate to the Iowa legislature.

In 1847 the Mormons' first companies went to Utah (then part of Mexico) from Winter Quarters. A year later, the federal government's permission for Mormons to be at Winter Quarters on Indian land expired, so hundreds moved across to Iowa. Miller's Hollow was renamed Kane in 1847 and Kanesville in 1848 in honor of Thomas L. Kane. ${ }^{65}$ Born in 1822, Kane was part of a prominent Pennsylvania family. In 1846 he visited the Grand Encampment, including the Mormon camps in Iowa, as an emissary of President Polk to help recruit the Mormon Battalion. In 1850 he delivered and published a sympathetic history of "The Mormons" before the Pennsylvania Historical Society, and he lobbied in Washington in behalf of the Mormon exiles. Later he helped negotiate peace during the "Utah War" in 1858, and was a regular adviser and friend to Brigham Young. He died in $1883{ }^{66}$

Kanesville became the hub of Mormon activities in southwestern Iowa. It served as county seat of Pottawattamie County, developed into a vital river port and trade depot on the upper Missouri, and was a main outfitting point for Mormons and gold seekers heading west. Because gold rush hordes needed food and supplies, Mormon residents found ready markets for their farm products, livestock, crafts, blacksmithing, and other services, and Kanesville prospered. Regarding Kanesville's settlers, a Pottawattamie County history written a half-century later noted,

Not only did they build the city, but the rich valleys became hives of industry; good crops were raised, which enabled them to assist their fellow pilgrims who were passing through. ... At this time the whole of Pottawattamie county, which was much larger than at present, as well as considerable adjoining territory, was under exclusive control of the Mormons. They made public sentiment,

65. William J. Petersen, "Kanesville," Palimpsest 42 (1961), 385-98.

66. American National Biography, s.v. "Kane, Thomas Leiper"; Leonard J. Arrington, "In Honorable Remembrance': Thomas L Kane's Service to the Mormons," Brigham Young University Studies 21 (1981), 389-402. 
controlled election of all public officers, and representatives of their faith sat in two sessions of the state legislature. ${ }^{67}$

Kanesville's population reached perhaps 3,000. In early 1852 the town contained 16 mercantile establishments, 2 drug stores, 2 printers, 5 hotels, 4 groceries, 8 wagon shops, 2 livery stables, 5 boot and shoemakers, 3 barbershops, 4 bakeries, and 6 blacksmith shops. Along Hyde Street (later First Street) were the Union Hotel, the Orson Hyde Music Hall, and a jail. Several Missouri River ferries operated near Kanesville. The most important were an upper ferry that crossed to where Florence, Nebraska, now is, a middle ferry at today's Council Bluffs, and a lower ferry that crossed to near present-day Plattsmouth, Nebraska. ${ }^{68}$

Kanesville served as the LDS church's headquarters for the United States east of the Rockies, with Apostle Orson Hyde as the presiding Mormon official. Between 1846 and 1852, hundreds of Saints were buried in Kanesville (now Fairview) Cemetery, possibly more than at the better-known Winter Quarters cemetery.

The Mormons built a large log building, the Kanesville Tabernacle, to be their main meeting hall. Constructed in three weeks in December 1847, it could seat 1,000. For more than a year it hosted conferences, elections, balls, socials, and meetings, until water seepage caused it to be dismantled late in 1849.

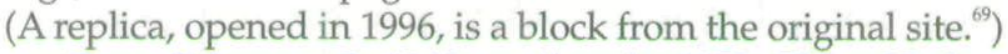

From February 7, 1849, until early 1852, Elder Hyde published the Frontier Guardian in Kanesville, a weekly and at times semiweekly four-page newspaper. Its pages kept Saints in the area informed about the progress of their church and promoted Kanesville's enterprises and overland trail outfitting capabilities among non-Mormon travelers. ${ }^{70}$

67. Homer H. Field and Joseph R. Reed, History of Pottawattamie County, Iowa, 2 vols. (Chicago, 1907), 1:8-9.

68. Frontier Guardian, 15 April 1852.

69. The tabernacle replica is in the Kanesville Historic Park, 222 East Broadway, filling most of a city block between Broadway and Kanesville Boulevard.

70. Douglas C. McMurtrie, "The First Printing at Council Bluffs," Annals of Iowa 18 (1931), 3-11; Jean Trumbo, "Orson Hyde's Frontier Guardian: A Mormon Editor Chronicles the Westward Movement through Kanesville, Iowa," Iowa Heritage Illustrated 77 (1996), 74-85. 


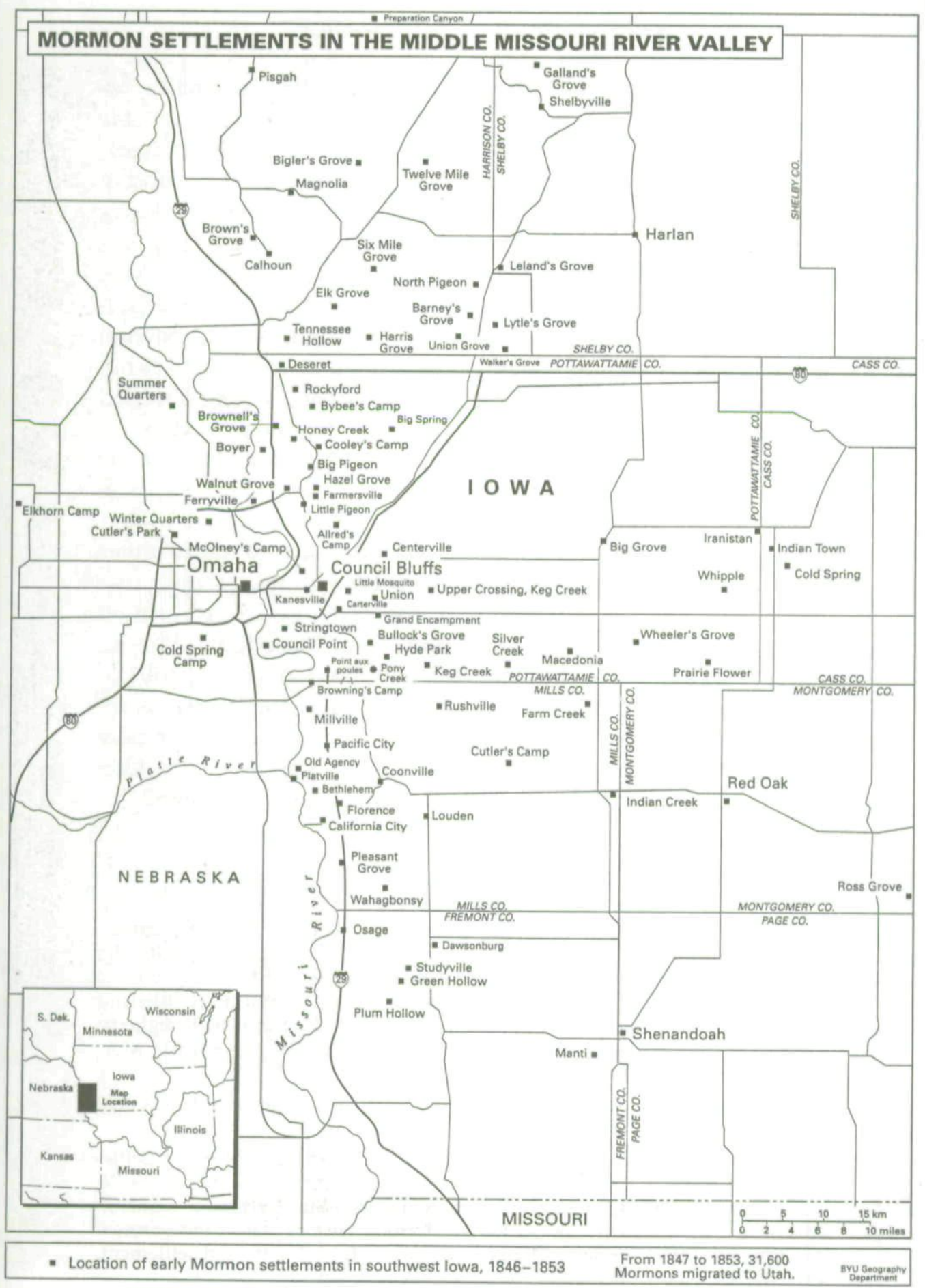

From Historical Atlas of Mormonism, by S. Kent Brown, et al (New York: Simon \& Schuster, 1994), map 37. Reprinted by permission of The Gale Group. 
From mid-1846 until 1852, Mormons settled in small clusters wherever water, timber, and farmable land could enable them to survive- up and down Mosquito Creek, Keg Creek, Silver Creek, Pigeon Creek, and their tributary streams. Today, thousands of descendants have genealogy records listing births, marriages, and deaths between 1846 and 1852 at such locations as North Pigeon Creek, Keg Creek, Six-Mile Grove, Twelve-Mile Grove, Harris Grove, Pottersville, Highland Grove, and Bullock's Grove. The Mormon settlement region extended beyond today's Pottawattamie County into Harrison, Mills, and other counties in the region. Local expert Gail Holmes has identified nearly 90 of the temporary Mormon settlements. ${ }^{71}$ At most, some 7,000 Saints lived at any one time in Kanesville and the nearby settlements. Many of them were LDS converts fresh from Europe stopping temporarily while on their way to Utah. ${ }^{72}$

One Mormon settlement, Macedonia, was about 20 miles east-southeast of Council Bluffs. Local tradition has held that Macedonia was not founded until the mid-1850s. But Mormon records show that in 1846, Mormons from Macedonia, Illinois, east of Nauvoo, moved en masse in a "Macedonia Company" to Pottawattamie County. By winter they had established themselves on the West Nishnabotna River and named their new settlement after their old place, Macedonia. A branch of the LDS church functioned there until the Mormons left Iowa in $1852 .^{73}$

71. Gail Geo. Holmes, "The Missouri River Valley," Historical Atlas of Mormonism, 74-75; Nancy K. Jaeckel, "Manti: The Life of a Shell-Bark Hickory Grove," Nauvoo Journal 6 (1994), 45-64; Danny L. Jorgensen, "Cutler's Camp at the Big Grove on Silver Creek: A Mormon Settlement in Iowa, 1847-1853," Nauvoo Journal 9 (1997), 39-51; Floyd E. Pearce, "Indiantown: The Mormon Settlement in Cass County, Iowa," Nauvoo Journal 6 (1994), 16-24; Ruth M. Dougherty, "Mormon Pioneer History of Harris Grove, Iowa" (paper presented at Mormon History Association annual meeting, May 1997).

72. Andrew Jenson, "Iowa," in Encyclopedic History of the Church of Jesus Christ of Latter-day Saints (Salt Lake City, 1941), 367.

73. Susan Sessions Rugh, "Conflict in the Countryside: The Mormon Settlement at Macedonia, Illinois," Brigham Young University Studies 32 (1992), 149-74; John Nealon, "Macedonia Transplanted: A History of the Latter-day Saints in Macedonia, Iowa" (paper presented at Mormon History Association annual meeting, May 1997). Today's Macedonia is one mile east of the old settlement. Old Macedonia became known thereafter as Old Towne. 
Between 1848 and 1852, Kanesville served as the Mormons' primary outfitting center for wagon trains going to Utah. ${ }^{74}$ Each year hundreds of Mormons arrived by riverboat or overland, some to continue west and others to stop temporarily before going on. New arrivals constantly replaced those heading west. Hundreds of river steamers from St. Louis and St. Joseph unloaded passengers and goods at Emigrants' Landing, now inland from the shifted Missouri River. ${ }^{75}$ During the Kanesville period, 28 sailing ships chartered by Mormons in England transported some 6,400 LDS converts to New Orleans, where Mississippi River steamers carried them up to St. Louis and on to Kanesville. ${ }^{76}$ An estimated 46 individual Mormon wagon trains departed from Kanesville during its days as an outfitting post. These trains involved about 2,800 wagons and more than 25,000 Mormons (see table 1). ${ }^{77}$

On September 21, 1851 the LDS Church Presidency instructed "all the Saints in Pottawattamie" to head for Utah the next season "and fail not," adding, "we wish you to evacuate Pottawattamie, and the States, and next fall be with us. ${ }^{178}$ In response, Saints across southwestern Iowa sold homes, farms, shops, and belongings, and departed during 1852. Their numbers set a record for Mormon Trail migration that year, nearly

74. An early look at Council Bluffs' role in the western migration is Nathan P. Dodge, "Early Emigration through and to Council Bluffs," Annals of Iowa 18 (1932), 163-79 (an account written in 1910). To understand Council Bluffs' importance as an outfitting city for all overland trail travel, see Merrill J. Mattes, "The Jumping-Off Places on the Overland Trail," in The Frontier Re-examined, ed. Francis McDermott (Urbana, IL, 1967), 27-39.

75. The site of Emigrants' Landing is in the SW $1 / 4$ of section 14, T74N R44W.

76. Andrew Jenson, "Church Emigration," 3 vols., LDS Church Archives. Conway Sonne authored two books about LDS ship and boat travel: Saints on the Seas (Salt Lake City, 1983), which is a narrative discussion, and Saints, Ships, and Mariners: A Maritime Encyclopedia of Mormon Migration, 1830-1890 (Salt Lake City, 1987), an encyclopedia of entries and photos of ships and boats the LDS Church chartered.

77. The following estimates of Mormons who went west, by year, as compiled by LDS historian Andrew Jenson, are found most readily in Kimball, Historic Resource Study: Mormon Pioneer National Historic Trail, 134: 1848 (4,000), 1849 $(3,000), 1850$ (5,000), $1851(5,000)$, and $1852(10,000)$. This totals 27,000, almost all of whom outfitted at or near Kanesville.

78. James R. Clark, Messages of the First Presidency, 5 vols. (Salt Lake City, 1965), 2:75-76. 
TABLE 1

MORMON WAGON COMPANIES DEPARTING FROM KANESVILLE, 1849-1852

\begin{tabular}{|c|c|c|}
\hline Departure Date & Wagon Company & No. of Wagons \\
\hline April 18, 1849 & Howard Egan & 22 \\
\hline ca. June 6,1849 & Orson Spencer/Samuel Gully & 100 \\
\hline July 4,1849 & George A. Smith \& E. T. Benson & 129 \\
\hline July 10,1849 & Silas Richards & 100 \\
\hline ca. July 12,1849 & Allen Taylor & 100 \\
\hline June 3,1850 & Milo Andrus & 51 \\
\hline before June 7,1850 & Benjamin Hawkins & 150 \\
\hline before June 7,1850 & James Pace & 100 \\
\hline before June 12,1850 & Aaron Johnson & 135 \\
\hline June 15,1850 & Joseph Young & 42 \\
\hline June 15,1850 & Warren Foote & 104 \\
\hline June 20,1850 & Wilford Woodruff & 44 \\
\hline June 20,1850 & Stephen Markham & 50 \\
\hline mid-June 1850 & David Evans & 54 \\
\hline July 4,1850 & Edward Hunter & 67 \\
\hline ca. May 1,1851 & John G. Smith & 150 \\
\hline ca. June 10,1851 & Easton Kelsey & 100 \\
\hline early June, 1851 & Garden Grove Co. & 60 \\
\hline June 21,1851 & James W. Cummings & 100 \\
\hline before July 7,1851 & Morris Phelps & 50 \\
\hline July 7,1851 & John Brown & 50 \\
\hline$?, 1851$ & Geo. W. Oman & 40 \\
\hline August 3,1851 & T. A. Williams/Freight & ? \\
\hline before August 12, 1851 & Wilkins Freight & 10 \\
\hline$?, 1851$ & Livingston/Kincade Freight & ? \\
\hline May 29, 1852 & James J. Jepson & 32 \\
\hline May 30,1852 & James W. Bay & 35 \\
\hline May 1852 & Benjamin Gardner & 45 \\
\hline ca. June 10,1852 & Joseph Outhouse & 50 \\
\hline early June 1852 & John Tidwell & 54 \\
\hline early June 1852 & Bryant and Jolly & 64 \\
\hline ca. June 24,1852 & Uriah Curtis & 51 \\
\hline mid-June 1852 & James C. Snow & 55 \\
\hline June 1852 & Isaac M. Stewart & 53 \\
\hline June 1852 & James McGaw & 54 \\
\hline ? 1852 & David Wood & 58 \\
\hline ? 1852 & 8th Company & ? \\
\hline ? 1852 & 13th Company & ? \\
\hline ? 1852 & Isaac Bullock & 22 \\
\hline ? 1852 & Henry W. Miller & 63 \\
\hline July 5,1852 & John B. Walker & 60 \\
\hline early July 1852 & Robert Wimmer & 130 \\
\hline early July 1852 & Eli B. Kelsey & 20 \\
\hline July 1852 & Allen Weeks & 45 \\
\hline
\end{tabular}

SOURCE: "Pioneer Companies That Crossed the Plains," 1997-98 Church Almanac (Salt Lake City, 1996, 167-76. 
double any previous year's totals. By the time eastbound Mormon Thomas Margetts reached Kanesville late in the summer of 1852, he had counted 1,400 Mormon wagons and some 10,000 Saints on the trail, westbound. ${ }^{79}$

In 1853 locals changed Kanesville's name to Council Bluffs. Mormon imprints from the seven-year period when what is now Council Bluffs was a Mormon settlement hub and outfitting city are extensive and have produced a substantial legacy of information and misinformation in many southwestern Iowa community histories, location names, art, and founding families.

Connection 6: Keokuk as Mormon Outfitting Camp (1853). Every year for 22 years between 1847 and 1868, Mormon emigrants outfitted in Iowa, Missouri, and Nebraska for their journeys to Utah. In 1853, the year after Mormons vacated Kanesville to avoid inflated prices there, Keokuk served as their outfitting place - a location 15 miles downriver from their abandoned city of Nauvoo. This year of large-scale Mormon outfitting and migration in Keokuk has yet to undergo major study.

In mid-April 1853, LDS emigrants began arriving by river at Keokuk. Agents created a large campground on the bluffs on Keokuk's northeastern edge (within the mile south of present Rand Park); made local arrangements to buy cattle, provisions, and wagons; and received one riverboat load after another of LDS emigrants. Among them was the first large LDS Scandinavian company heading for Utah, the John Forsgren Company. Some 2,500 English, Scottish, Welsh, Scandinavian, French, and Dutch Saints were organized into nine wagon companies. One of the travelers was 23-year-old Frederick Piercy, a professional painter from England, whose Route from Liverpool to Great Salt Lake Valley, a classic of overland trail literature, combines narratives and 45 drawings (including the Keokuk encampment). ${ }^{80}$

\section{Jenson, "Church Emigration," 417.}

80. Frederick Piercy, Route from Liverpool to Great Salt Lake Valley, Illustrated, edited by James Linforth (Liverpool and London, 1855); Wilford Hill Lecheminant, "'Entitled to Be Called an Artist': Landscape and Portrait Painter Frederick Piercy," Utah Historical Quarterly 48 (1980), 49-65. A 1996 regional tourism brochure, The Western Adventurer, stated erroneously that 3,000 Mormons outfitted there in wagon trains of 100 wagons each (22). 
Keokuk's mayor and other influential men tried to accommodate the Saints and their needs. Because it took time for LDS agents to find and purchase the needed oxen and wagons, some emigrants waited at Keokuk nearly a month. Capitalizing on the availability of cheap labor, the city hired them to improve Keokuk's poor streets, which were "little more than lanes" that rain turned into seas of sticky mud. Businesses developing back from the waterfront demanded better streets, so the city council contracted with Mitchell Marshall to grade Main Street and build Plank Road. By May 27, Main Street was nearly graded, presenting a straight and unbroken avenue of nearly a mile. Mormons, a local history credits, played a key part "in making the muddy lanes of Keokuk into proper streets." ${ }^{81}$

Ten covered wagon companies, including one freight train, left Keokuk between mid-May and July 1, 1853 (see table 2). Wagon sides bore inscriptions such as "The Lord's House shall be established on the tops of the mountains" and "And all nations shall flow unto it." These companies crossed Iowa using various routes, thereby becoming the source of local traditions in Pella and elsewhere about Mormons having passed that way - traditions that have confused the 1853 Mormons with 1846 Nauvoo exodus companies. The Forsgren Company's route included New Boston, Farmington (where the company crossed the Des Moines River), Stringtown, Drakesville, Unionville, Chariton, and Mt. Pisgah. The Joseph W. Young Company went to New Boston and then northwest along the Keokuk-to-Des Moines Road. They passed through or by Charleston, Winchester, and Birmingham, camped two miles west of Libertyville, passed through Agency City, proceeded along the Des Moines River, passed Ottumwa, and on June 14 camped four miles east of Eddyville. The Weekly Oskaloosa Herald of June 17 reported that about 750 Mormons, principally from England and Wales, had passed through Oskaloosa the day before (apparently another wagon train was with Young's Company of only 402 people). They had ox teams, one outfit for every twelve persons.

81. Piercy, Route from Liverpool, 90-91, 201; The History of Lee County, Iowa (Chicago, 1879), 622; Alois J. Weber, History of Mormon Encampment at Keokuk in 1853 (Keokuk, 1963). 
TABLE 2

LDS WAGON COMPANIES OUTFITTING IN KEOKUK, 1853

\begin{tabular}{|c|c|c|c|}
\hline Departure Date & Company & People & Wagons \\
\hline May 18 & Jesse W. Crosby & 79 & 12 \\
\hline May 16 & Moses Clawson & 295 & 56 \\
\hline May 21 & John E. Forsgren & 294 & 34 \\
\hline June 3 & Joseph W. Young & 402 & 54 \\
\hline June 3 & Cyrus H. Wheelock & 400 & 52 \\
\hline June 3 & Claudius V. Spencer & 250 & 40 \\
\hline ca. June 3 & Jacob Gates & 262 & 33 \\
\hline June 15 & Appleton Harmon & 200 & 22 \\
\hline July 1 & Henry Ettleman & 40 & 11 \\
\hline July 1 & John Brown & 303 & 50 \\
\hline & & 2,525 & 364 \\
\hline
\end{tabular}

NOTE: In addition, 2 Mormon companies outfitted in 1853 near Council Bluffs.

SOURCE: "Pioneer Companies That Crossed the Plains," 1997-98 Church Almanac (Salt Lake City, 1996), 167-76.

They plodded through Pella, camped at Mitchell, and then turned onto the Des Moines-to-Council Bluffs Road that went through Winterset. Elizabeth Griffiths, from Pembrokeshire, England, died east of Winterset and "was buried on the prairie." The Young Company intercepted the 1846 Mormon Trail route at the Middle Nishnabotna River, then followed it past Indiantown and on into Council Bluffs-a 327-mile trek in total. ${ }^{82}$

These 1853 LDS wagon trains made the Iowa crossing in an average of four weeks even though, as James Ririe recalled, "across Iowa the roads were bad and we greenhorns poor teamsters. ${ }^{183}$ Other than a handful of accidents, they traveled in good condition. Their Iowa crossing attracted the attention of locals in towns and in the country, and interactions between them and local people became the stuff of which family and local lore was made.

82. "A Pioneer Journal, Forsgren Company, Containing the Story of the First Danish Company to Emigrate to Utah," Heartthrobs of the West 6 (1945), 16-20; Joseph W. Young Company Journal, kept by Henry Pugh, May 27, 1853, in Journal History, 10 October 1853, 5.

83. "James Ririe-Archibald McFarland," Our Pioneer Heritage 9 (1955), 335. 
Connection 7: LDS Handcart and Wagon Companies, 18561858. Handcarts have become the primary visual symbol of the entire Mormon migration west. Even Iowa Mormon Trail reenactments in 1996 included people pulling handcarts. Three false images circulate concerning the handcart brigades: that the 1846 wagon trains included some handcart pioneers; that a high percentage of Mormon emigrants went west in handcart companies; and that most handcart emigrants met with disaster in Wyoming snows. With the sesquicentennial of the handcart saga approaching in 2006, it is important to convey accurate information about the handcart brigades in Iowa-what the system was, how it worked, what routes they followed, and what their experiences crossing Iowa were like.

Between 1856 and 1860, Mormons organized ten handcart brigades, involving 3,000 LDS travelers, mostly from Europe. Seven of the ten crossed Iowa. ${ }^{84}$ In 1856 the LDS church devised the system of handcart companies whereby emigrants who could not afford the expense of covered wagons and four oxen could pull small, inexpensive handcarts the 1,300-mile distance. Because most travelers in oxen-pulled wagon trains walked instead of rode, the type of vehicle used to go west related more to baggage hauling than to people moving.

Advantages the handcarts offered were obvious in that wagon era. Low cost was one. Faster daily travel was anotherhandcart companies could move faster than oxen. Because they did not need to hitch and unhitch and rest and feed and water oxen, they could leave earlier and travel longer each day. The handcart pullers did not need to find campsites offering grass and water for oxen. They were spared the intense labor involved with oxen-hitching, unhitching, double yoking to go uphill, getting them across rivers, taking them to pasture at midday and every night, watering them, guarding them at night, and rounding them up each morning. They did not have to worry about oxen injuries or illness. Disadvantages of the handcarts were that people had to power the carts themselves; the small carts could carry only bare essentials; and the travelers had no protection during the day from sun, wind, and rain like that pro-

84. Hafen and Hafen, Handcarts to Zion, 30-37. 
vided by covered wagons (they did have big group tents to sleep in at night).

The outfitting campground site for the 1856 and 1857 handcart companies was in present Coralville, on Iowa City's northwestern shoulder. ${ }^{85}$ Mormons who joined the handcart companies reached Iowa City by train from the East Coast. Orson Spencer had on-site responsibility for the 1856 handcart outfitting, with advice from LDS Apostles John Taylor and Franklin D. Richards. Wagon expert Chauncy Webb was the camp's main wheelwright. Designs for fabricating the carts came from church headquarters in Utah. The first companies employed four different handcart designs, experimenting to see what worked best. Workers at the outfitting camp as well as wheelwrights in Iowa City and St. Louis constructed the two-wheeled handcarts, usually of hickory or oak. In the first year, 100 carts were built at St. Louis, 100 in Iowa City, and about 70 at the campground. In response to Brigham Young's direct orders, green wood was used in some hubs, which contributed to later breakdowns. ${ }^{86}$

The covered family carts each had a small wagon box three or four feet long with the side and end boards about eight inches high, while the larger, open carts had no covers or sideboards. Carts were designed with an extended rectangular handle in front by which two people could pull the cart. One journal entry described the carts this way: "The carts which are delivered to us are well constructed and light. They have very strong wooden wheels, four feet high. The rim is made of two ... fellies around which is fastened an iron tire. They have wooden axles upon which are attached two shafts eight feet long and

85. This location was then part of Iowa City. The site is two miles WNW from Iowa City's central business district. The park is located off Mormon Trek Boulevard, which skirts the western edge of the University of Iowa campus and is accessed through the Hawkeye student housing complex. From the park's parking lot, a paved 1/2-mile path goes westerly up to the level fields that were the handcart campgrounds. Along the path are three interpretive signs, erected in 1979, that explain the 1856 "handcart brigades."

86. Don Smith, an orthodontist in Pullman, Washington, and an expert on the Willie Handcart Company, has written but not published "Dispelling Myths Created by the Handcart Emigration of 1856," undated typescript, 29 pp., copy in author's possession. In it he gives the information above about where handcarts were built and their numbers (24-25), says that four designs were tried out (23), and discusses the order to use green wood for hubs (27). 
five matching cross pieces. The carts are four feet wide and weigh 60 pounds. ${ }^{1{ }^{87}}$

According to a common myth, the handcart loads weighed 600 pounds. The truth is that each cart was built to carry about 100 pounds of food, clothing, and equipment, and the actual load was usually 100-150 pounds. Each handcart traveler was limited to 17 pounds of baggage apiece. Four or five persons were assigned to each cart, with 20 assigned to each large, round tent that the LDS agents provided. One wagon and team accompanied each 20 carts, hauling the heavy tents, food, and equipment, and carrying incapacitated travelers when necessary. Mule team wagons kept up with the handcarts; wagons pulled by oxen had to travel longer days to keep up. ${ }^{88}$

On August 2, 1856, the New York Evening Post published a non-Mormon's description of the Iowa City camp when it was near its fullest, busiest time.

The camp, as viewed from the brow of a neighboring hill ... presents a fine spectacle. Over one hundred tents, and perhaps as many covered wagons, with their spires and arches of dazzling white-contrast well with the green sward of prairie and the sparkling ripples of the river running close beside.... In all about three thousand have rendezvoused in this spot, of whom some eighteen hundred still remain. ... The tents are arranged in rows, with wide streets between them-the wagons generally in rings, with the entrance at one side, and sleeping tents on the outside. ... There are in all four hundred and forty-five oxen, twenty mules, and a few horses.... There is seen, as you enter camp, a smithery, a workshop and a store, all full of business and industry. ... I have made acquaintance of their leaders, and have found them courteous, cultivated, and in business transactions, uncommonly 'sharp. ${ }^{, 89}$

The first two handcart companies, captained by Edmund Ellsworth and Daniel McArthur (both returning from missionary service in Great Britain), left the outfitting grounds on June 9 and 11, 1856, and traveled close together all the way to Utah. Together, they contained 497 people, 100 handcarts, 5 wagons,

87. Peter Madsen, Journal, holograph in Danish, LDS Church Archives.

88. Hafen and Hafen, Handcarts to Zion, 53-56.

89. New York Evening Post, 2 August 1856. 
24 oxen, 4 mules, and 25 tents. Their wagons hauled provisions to last them until they reached Florence, Nebraska Territory, 275 miles to the west, where they were reprovisioned. Both companies arrived in Florence on July 8, the Ellsworth Company 27 days after starting, the McArthur Company 25 days.

On some days the handcart travelers in Iowa walked and pulled 20 miles or more. On July 1, diarist Archer Walters, in the first company, noted that he had "traveled about 15 miles. Walked very fast,-nearly 4 miles an hour." Twenty-four-yearold Twiss Bermingham, a Dublin University graduate, traveling with his wife and three children, wrote on July 3 that the McArthur Company started at 5 a.m. and traveled "a long and tedious journey of 25 miles" before camping at 7:15 p.m. Iowa's humidity and summer heat took a toll, he noted: "Some of the Brethren fainted on the road and were carried into camp in the ox-team. I nearly fainted myself from exhaustion." Bermingham said the McArthur Company's people reached Florence City "generally very fatigued," in dust-stained clothes, and with sunburned faces. ${ }^{90}$

Returning missionary Edward Bunker led the third company, which contained mostly Welsh Saints-320 persons, 64 handcarts, and 5 wagons pulled by mule teams. They left Iowa City on June 28 and reached Florence July 19-a record-setting 22-day journey. While crossing Iowa they encountered "heavy rain and wind storms which blew down our tents and washed away our handcarts," Bunker recalled. Priscilla Evans noted that "People made fun of us as we walked, pulling our carts," but admitted that although "we were very tired at night, still we thought it was a glorious way to go to Zion." ${ }^{\prime 11}$

John D. T. McAllister, one of the officials who disbursed equipment and supplies at the outfitting camp, wrote a "Handcart Song" that was sung by many handcart pioneers-and by Latter-day Saints ever since.

Ye Saints who dwell on Europe's shore

Prepare yourselves with many more

90. Hafen and Hafen, Handcarts to Zion, 61, 62, 63.

91. Ibid., 83; Gaylen K. Bunker, The Annotated Edward Bunker (Salt Lake City, 1992), 77. 
To leave behind your native land For sure God's Judgments are at hand.

Prepare to cross the stormy main

Before you do the Valley gain, And with the faithful make a start

To cross the plains with your handcart.

Chorus:

Some must push and some must pull

As we go marching up the hill,

And merrily on the way we go

Until we reach the Valley, oh! $!^{92}$

Of the five handcart companies that crossed Iowa in 1856 (six if counting Jesse Haven's division of the Martin Company), the Ellsworth, McArthur, and Bunker companies made the long, strenuous trek to Utah successfully. But the last two, the illfated James G. Willie and Edward Martin companies, left late because they were inundated with unexpected passengers and needed extra time to find additional handcarts and supplies. After problems and slowdowns in Nebraska, they were trapped by severe blizzards in Wyoming, and some 200 out of 1,076 lost their lives. ${ }^{93}$

In 1857 the Israel Evans and Christian Christiansen handcart companies were the last to use Iowa City for outfitting. (The final three handcart companies, which made the trek in 1859 and 1860, started from Florence, Nebraska Territory, not Iowa.) J. F. F. Dorius, in the Christiansen Handcart Company, noted in his journal that his group reached Iowa City on June 9, 1857 , and went to the camp, where they found tents pitched in circle-like fashion, one tent to accommodate 18 people. "Each family obtained a handcart from the railroad station," he said. Three days later they broke camp and pulled their handcarts westward. "I felt glad in enjoying this free life outdoors," he

92. Hafen and Hafen, Handcarts to Zion, 65-66.

93. Ibid., 91-117; Stella Jaques Bell, Life History and Writings of John Jaques, Including a Diary of the Martin Handcart Company (Rexburg, ID, 1978); Lynne Slater Turner, ed., Emigrating Journals of the Willie and Martin Handcart Companies and The Hunt and Hodgett Wagon Trains (Salt Lake City, 1996); Howard A. Christy, "Weather, Disaster, and Responsibility: An Essay on the Willie and Martin Handcart Story," Brigham Young University Studies 37 (1997-98), 6-74. 
wrote that day. But so many became sick by mid-June that the four mule-pulled wagons became filled to capacity. An elderly woman died in camp on June 21 and was buried "in the woods. ${ }^{\prime 94}$ (Such non-cemetery burials by Mormon wagon and handcart companies became the source of many Iowans' local traditions about Mormon graves being on lands they now own.)

In addition to the first seven handcart companies, nine LDSsponsored wagon trains outfitted at Iowa City in 1856, 1857, and 1858. These nine companies, named for their captains, were the William B. Hodgetts and Dan Jones (then John A. Hunt) companies, which left in 1856; the Jesse B. Martin, Matthias Cowley, Jacob Hoffheins, and William G. Young companies, in 1857; and the Horace S. Eldredge, Iver N. Iverson, and Russell K. Homer companies, in $1858 .^{95}$

The 111-mile stretch of US Highway 6 from Iowa City to Des Moines closely parallels the old river-to-river road along which the 1856 and 1857 handcart brigades traveled. They passed where South Amana now is and rolled along one mile south of Marengo. (A young traveler in the first handcart company, Job Welling Jr., not quite two years old, died on June 17, 1856, near present-day Grinnell and was buried the next day.) ${ }^{96}$ The handcart route continued westward. When the Willie Company went through Newton on July 28, "it appeared as if the residents of the entire city and the country round about were lining the streets as they walked along." ${ }^{197}$ Turning southward, the handcart brigades passed through Mitchellville and into Des Moines, where they crossed the Des Moines River. At Adel, the travelers forded the North Raccoon River and moved on to present-day Wiscotta and then west to the now vanished town of Dalma94. J. F. F. Dorius, Journal, typescript copy, in Journal History, entry for 13 Sep-
tember 1857.

95. Kimball, Historic Resource Study: Mormon Pioneer National Historic Trail, 144.

96. Hafen and Hafen, Handcarts to Zion, 200. The Job Welling Jr. grave marker is about 50 miles east of Des Moines. The site is $1 / 2$-mile north of I-80 via the Grinnell Exit (State Route 146), then 21/4 miles west on an unnumbered county road to a sharp bend to the south. The grave marker is in a sloping yard on the NW side of the bend, T80N R17W, Sec. 25.

97. Journal of James G. Willie, family typescript, copy in author's possession. 


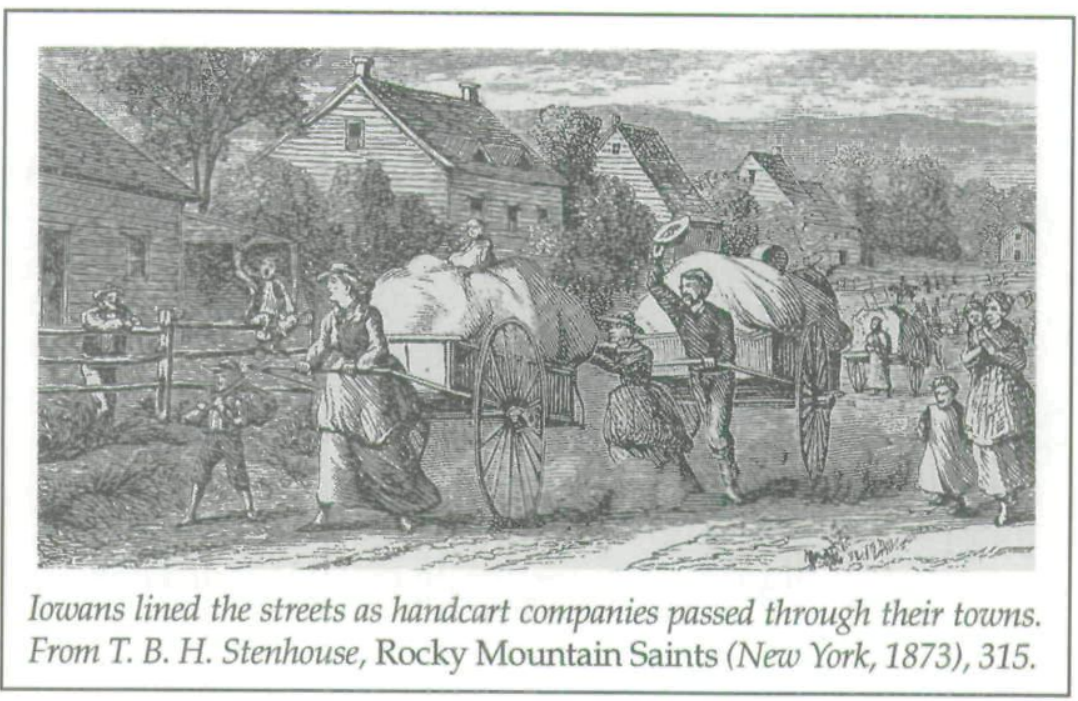

nutha (41 miles west of Des Moines). ${ }^{98}$ They walked for many miles beside Turkey Creek, following closely present-day State Route 83. At Lewis, the handcart route joined the 1846 Mormon Trail route and followed it into Council Bluffs. They moved north and crossed the Missouri River at Florence, Nebraska.

Connection 8: Mormons Who Did Not Go West. Some Mormons who remained loyal to Brigham Young stayed in Iowa. Many had family members who physically could not make the journey west. Some feared leaving civilization behind to go west. Others did not want to abandon successful farms or businesses. Most Mormons who did not go west, however, refused to retain an association with the LDS church. Some lost faith in the church's leadership, including many who objected to the practice of polygamy. Devout Mormons' diaries and sermons sometimes noted those who left the fold during the 1846 exoduses, the handcart journeys, the stopovers at and near Kanesville, the 1853 wagon train crossings of Iowa, and at other times.

98. All that remains of Dalmanutha is a cemetery (approximately 40 miles west of Des Moines and 7 miles north of Casey). It contains a sign that tells about Dalmanutha's history. It says that Mormon handcarts passed that way, but the text contains numerous factual errors. 
Also, a moderate number of "back trailers" came back from Utah and settled in Iowa. No one has attempted to estimate the number of disaffected Mormons who became Iowa residents, but there were hundreds, perhaps a few thousand. Some found other institutional forms to express their Mormon faith. After a group of Mormons organized the Reorganized Church of Jesus Christ of Latter Day Saints (RLDS church) in Illinois in 1860, hundreds of Iowa Mormons joined it. ${ }^{99}$ Others joined local churches, or gave up on all forms of organized religion. ${ }^{10}$

Mormons who remained in or returned to Iowa, whether followers of Brigham Young or not, became pioneers and sometimes pillars in many southwestern Iowa communities, including Council Bluffs, Macedonia, Woodbine, Manti, Blockton, and Coonville. ${ }^{101}$ For example, in 1851 Mormons Lorenzo Dow and Ann Binnall Butler moved north of Kanesville about 30 miles to Twelve-Mile Grove. They chose not to go to Utah because they disliked polygamy. They took up land, Lorenzo built a grist and sawmill, and they opened a store. When the area received a post office, Ann became postmistress and named the place Woodbine, the name of the English cottage where she once lived. Woodbine, in Harrison County, became Lorenzo and Ann's lifelong home. ${ }^{102}$

Today in Potter's Park in Harlan, Shelby County, there are two $\log$ cabins that local tradition says were built by Mormons who did not go west- the John A. McIntosh Cabin (1857) and the Benjamin Leland Cabin (1856). Two miles southwest of present Shenandoah in Fremont County is the site of a Mormon set-

99. Pearl Wilcox, Roots of the Reorganized Latter Day Saints in Southern Iowa (Independence, MO, 1989), contains histories of various RLDS branches and converts in Iowa and shows how the RLDS church began.

100. In late 1855 Andrew Cunningham went east from Utah on Mormon church assignments in the Iowa-Nebraska area. He found many Mormons who had rejected Brigham Young's leadership and disliked Rocky Mountain Mormonism, particularly polygamy. Many Iowa Mormons he visited were ones with whom he had associated before he went to Utah, but "they had so far departed from the true spirit of the gospel that I had no pleasure in their society." See Journal History, 16 August 1857, 1.

101. For examples, see Wilcox, Roots of the Reorganized Latter Day Saints, 34-55. Coonville was renamed Glenwood.

102. Hartley, My Best for the Kingdom, 238-39; "Mrs. Ann Butler Answers Summons," obituary article in unidentified Woodbine newspaper, 20 March 1914, photocopy in author's possession. 
tlement named Manti. Manti was founded by 20 families who were following a Mormon leader named Alpheus Cutler. By the time they established a separate church in 1853, 102 "Cutlerites" lived in Manti. Most of them later joined the RLDS Church. ${ }^{103}$ In 1861 a dozen Cutlerite families moved from the Manti area two counties east into Taylor County and settled on a lovely site beside the Platte River. They built two mills and stayed until 1865. Locals called the settlement Mormontown. After the founding families left, Mormontown became the largest village in Jefferson Township, and in 1888 its name was changed to Blockton. ${ }^{104}$

\section{THESE EIGHT SEPARATE CONNECTIONS of Mormons} with early Iowa history and places are the most distinguishable ones and the ones involving the largest number of participants. In addition, Mormons individually stopped in and passed through Iowa during this period, no doubt contributing in some cases to local traditions about Mormons having been there. Mormons' encounters with early Iowa provided short-term and long-term benefits to the territory and state, including improved roads, new roads, bridges, hired laborers, farms, fences, houses, mills, industries, place names, government officials, voters, and consumers. Their routes and improvements hastened and eased the settling of southern and western Iowa.

Although these accounts of eight Mormon connections to early Iowa are short and not exhaustive, they may enable Iowa and LDS historians as well as Iowa communities and residents to better differentiate among the early Mormon encounters; understand sequences and developments; determine how artifacts, traditions, early histories, and historical documents properly relate to Mormon involvement in early Iowa; and evaluate the Latter-day Saints' contributions to early Iowa's land and resource development.

103. Danny L. Jorgensen, "The Cutlerites of Southwestern Iowa: A Latter-day Saint Schism and Its Role in the Early Settlement of Iowa," Annals of Iowa 58 (1999), 131-61. Manti has disappeared, but its location was about two miles south and west of present Shenandoah.

104. History of Taylor County, Iowa (Des Moines, 1881), 597-99. 
Copyright of Annals of Iowa is the property of State of Iowa, by \& through the State Historical Society of Iowa and its content may not be copied or emailed to multiple sites or posted to a listserv without the copyright holder's express written permission. However, users may print, download, or email articles for individual use. 